\title{
The importance of continued collecting of bird specimens to ornithology and bird conservation
}

\author{
J. V. REMSEN, JR.
}

\section{Summary}

Because museum scientists and conservationists are natural allies in the struggle to preserve biodiversity, conflict over the legality, morality, and value of collecting scientific specimens is counterproductive. Modern bird specimens contain a variety of data, summarized briefly herein, that are applied to numerous questions concerning the biology of birds, many of which have direct and often critical relevance to conservation. In particular, continued collecting of specimens has been shown to be critical in determining species-level classification in birds; unless species limits are established correctly, conservation priorities cannot be established reliably. Objections to collecting specimens are summarized and discussed. Calculations are presented to show that the effect of collecting specimens on most bird populations is insignificant. Moral objections to collecting specimens seem to reflect a lack of awareness of the extent and causes of natural mortality, as well as a failure to recognize the magnitude of unintentional mortality inflicted on bird populations by routine human activities. The reason why more specimens are needed than currently exist in museum collections is that most existing specimens lack the data needed for most kinds of modern analyses, and even common species are represented by inadequate samples for research. Reasons are given for why equivalent data cannot be obtained solely from living birds that are subsequently released. Objecting to collecting specimens because it sets a bad example for developing countries trying to establish an environmental ethic is counterproductive in that it draws attention away from the fundamental units of concern for conservation biology: the population, and the habitat that supports it. Biological specimens differ from some other scientific specimens (e.g. archaeological) in that they are renewable resources whose removal does not deplete a country's national heritage. Misconceptions about museum scientists and their motives are discussed. Regarding collecting permits, recommendations are presented concerning (1) numbers of specimens, (2) percentage of specimens left in the host country, (3) species composition, (4) deposition of specimens, and (5) processing permit applications. Regulating agencies are often overly enthusiastic in restricting scientific collecting, which is the only kind of mortality that is so highly controlled and yet from which bird species might derive benefit, whereas the same or sister agencies often permit and even encourage activities that are responsible for massive mortality in bird populations. Given that (1) the goal of scientists, conservation agencies, and governments is protection of populations, not individual birds; (2) scientific collecting has no measurable impact on the vast majority of bird populations; (3) scientific specimens represent an important source of information on bird biology and conservation; and (4) existing scientific collections are largely inadequate for answering many questions that could be answered with greater numerical, seasonal, or geographic 
representation, then it follows that continued scientific collecting will benefit ornithology and conservation and should, therefore, be encouraged by conservation and government agencies.

\section{Introduction}

As concerns for bird conservation increase, those who collect birds for scientific research have come under increasing pressure to justify this activity. In many cases, however, no chance for justification is given by permit-granting agencies, which often make decisions without input from scientists and seldom provide justification for the limits imposed. Collecting permits for birds are difficult or impossible to obtain in many areas, and in many others the numbers of species and specimens per species that can be taken have become so restrictive (e.g. Liversidge 1975) that specimen-based research has been curtailed severely. Opposition to killing birds for any reason is in part an outgrowth of the worldwide environmental movement. Much of the rationale behind this opposition is: how could anyone concerned with the welfare of birds condone killing them, and how could this possibly benefit conservation?

This paper addresses this apparent paradox and expands on my previous paper on the topic (Remsen 1991). Conservationists, wildlife managers, permit agencies, and scientists should all be allies in the struggle against environmental destruction. The information gained by collecting of scientific specimens aids conservation efforts without hurting bird populations, but scientists have done a poor job of communicating that fact to those who issue permits. Unfortunately, some conservationists and permit agencies seem to have lost sight of the proper unit of conservation, which is the population (and the ecosystem that supports it) rather than the individual. Failure to grasp the significance of this point threatens to weaken the conservation movement.

The purpose of this paper is first to summarize briefly the kinds of information provided by specimens and then to show why continued collecting is needed and how such specimens can be used to aid the conservation of birds. I also address the arguments presented by those opposed to collecting specimens and make recommendations concerning issuing permits for scientific collecting of birds.

\section{The value of specimens}

The value of bird specimens to many kinds of research is well appreciated by most scientists. Details of how specimens are useful for particular projects can be found in Winker et al.'s (1991) excellent summary and in the references below. The fields of avian taxonomy, systematics, zoogeography, geographic variation (Baker 1985), anatomy and morphology (Bock 1985, Raikow 1985), sexual dimorphism, age/gender characters, moult, and plumage sequences (Parkes 1963), ecomorphology (Ricklefs 1980, Fitzpatrick 1985), and ontogeny (Alberch 1985) depend on specimens. Less well-known is that information from bird specimens can provide important data for studies of population biology (Ricklefs 1980, Allen and Cannings 1985), timing of reproduction (Parkes 1963), migration (Parkes 1963, Ramos 1988), social behaviour (Miller 1985, Møller 
1991), food webs and energy flow (e.g. Hobson and Sealy 1991), and wildlife management (Banks 1979a, Barlow and Flood 1983). Series of skeletal specimens of modern species are obviously critical to avian paleontology (e.g. Storer 1988), and identification of avian material in archaeology and anthropology also depends on specimens. Specimens are also the basis for virtually all scientific illustration in birds, from field guides to technical literature. With the advent of molecular techniques for studies of systematics and population genetics, new ways of investigating questions in bird biology have increased the importance of collecting new material (Barrowclough 1985). The combined analysis of genotype (molecular samples) and phenotype (plumage, morphology, behaviour, etc.) can provide dramatic new insights into avian evolution (Hackett and Rosenberg 1990, Lanyon 1992, Peterson and Burt 1992, Richman and Price 1992, Sheldon et al. 1992, Winkler and Sheldon 1993), including the little-understood but vital role of environmental factors in determining body shape and size (James 1983, Burns 1993). With the recent worldwide emphasis on "biodiversity" (e.g. Ehrlich and Wilson 1991, Raven and Wilson 1992), bird collections take on new significance. Indeed, collections are the means by which future changes in characteristics of populations can be monitored (Winker et al. 1991). Analysis of specimens has revealed evolutionary change over time-spans of just a few decades for some introduced (e.g. Johnston and Selander 1971, Blem 1975, Aldrich and Weske 1978, Ross 1983, St. Louis and Barlow 1988, 1991, Baker et al. 1990) and natural (Zink 1983, Smith et al. in press) bird populations, and it is suspected for other natural ones (Marshall 1948, Remsen 1984). All in all, bird collections are widely recognized as crucially fundamental to research in ornithology (Parkes 1963, Foster 1982, Barlow and Flood 1983, Diamond 1987, Fjeldså 1987, Winker et al. 1991). However, a chronic problem for ornithologists seeking to collect birds is that the vast majority of non-scientists incorrectly assume that we already know "everything there is to know" about birds (at least in North America and Europe), or that the specimens in museums suffice to answer all remaining questions. Convincing them that continued collecting is important has become a major obstacle to research.

The value of a specimen depends on the information contained on its label. Most museum specimens have at least the following data: ( 1 ) precise locality, (2) date of collection, and (3) sex. Study skins with these data can be used in the following types of analyses: geographic variation and taxonomy (using both plumage and morphometric characters), seasonal and geographic distribution, zoogeography, moult, sexual dimorphism, and age/sex ratios. Specimens missing any of these basic data categories are of lesser research value. Just in the last few decades, thousands of scientific papers have been published on the above topics using specimen data. These papers form the core body of knowledge about the evolution and ecology of birds and base-line data on bird biology. More will be written every year.

Modern study skins have additional data that describe precisely the origin and condition of the specimens and are useful for many additional kinds of analyses (Foster and Cannell 1990). These include:

(1) elevation

(2) reproductive condition 
(3) subcutaneous fat levels

(4) body mass

(5) degree of skull ossification as an index of age

(6) presence and size of the bursa of Fabricius as an index of age

(7) colours of those parts of the specimen that disappear or change after death, namely iris, eyelid, bill, facial skin, mouth-lining, tarsi, and toes

(8) internal and external indications of moult

(9) stomach and crop contents

(10) presence of ecto- and endoparasites

(11) method of capture, habitat, microhabitat, and behavioural data.

These additional data can be used in studies of the biology of birds too numerous to list here. For species of tropical forests, where nests are characteristically difficult to find and sample sizes adequate for analysis nearly impossible to obtain for many species, analyses of gonad data from specimens (e.g. Miller 1959, 1962, 1963, Foster 1975, Remsen 1985, Willard et al. 1991, Chapman in press) may be the most feasible way to determine timing of breeding. Most modern specimens are also accompanied by notes on the behaviour and habitat of the individual when collected.

Most modern study skins are also now accompanied by varying kinds of ancillary material or data cross-referenced to the study skin. These may include:

(1) tissue samples for biochemical analysis

(2) preserved stomach and crop contents

(3) parasites

(4) blood smears for blood parasite analysis

(5) varying amounts of anatomical material, such as a nearly complete skeleton or carcass (Johnson et al. 1984), or a spread wing (for studying feather shape, wing shape, wing-loading ratios, and certain colour and moult patterns difficult to assess from standard study skins)

(6) nests

(7) eggs

(8) tape-recordings of vocalizations

(9) foraging data.

Again, such material permits numerous additional investigations of the biology of birds.

Unfortunately, many opponents of scientific collecting, who often think that specimens serve only as a "primitive" means to "document the presence" of a species (e.g. Dunne 1988, McGeehan 1993, Mitchell 1994), are clearly unaware that modern specimens have such an extraordinary amount of information that in turn stimulates diverse research projects, including many with direct and indirect relevance to conservation (see below), or proclaim that any knowledge gained from specimens is simply not worth the life of a bird. Many amateur ornithologists and unfortunately, as noted by Phillips (1974) and Remsen (1993), some misinformed scientists are not aware that the purpose of collecting extends 
beyond species identification, particularly with regard to extralimital ("vagrant") records. In fact, only a tiny fraction of the museum specimens in the last several decades were collected solely to document species identification, but even those few specimens consequently provide additional information. My experience with introducing amateur ornithologists to the data provided by modern specimens is that their typical reactions are surprise, excitement, and new appreciation of why specimens are collected (for an example of the wealth of new data on the biology of a species provided by just a few modern specimens, see Lee and Clark 1993). All collectors have a responsibility to maximize data from each specimen.

This paper is not the forum for debate over sight versus specimen records of birds. Briefly, sight records alone can be unreliable for documenting bird distributions. Phillips (1975) showed unequivocally that even experienced birdwatchers are capable of widespread, chronic errors in field identification of even common birds in a well-known region, and that these have led to huge errors in knowledge of bird distribution. The problem can be much worse in less well-known, tropical regions, even at frequently visited sites. Identification of individual birds of unfamiliar species is even more perilous (e.g. Morlan and Erickson 1983). Yet in the face of such facts, some birdwatchers continue to manifest the belief that "birds are as identifiable in the field as they are in the hand" (Dunne 1988).

An under-appreciated importance of specimens is the inspiration that they provide for research. From beginning students to veteran museum ornithologists, mere browsing through collections has stimulated many research ideas, resulting in projects from laboratory to field. The three-dimensional, hands-on experience of exploring simultaneously the morphology, coloration and individual variation within or among taxa in a research collection cannot be matched by any other setting.

Perhaps the greatest value of specimens and the continuing need for collecting them is that their immediate research value cannot necessarily predict their future importance. Specimen-based research is full of unanticipated, unpredictable surprises (Arnold 1991). Undescribed new species and even new genera may lie in collections for decades before recognized as such (e.g. Graves 1987, 1988, 1993, James et al. 1989). Those who collected a century ago could not have foreseen that their specimens would be analysed for levels of toxic chemicals for comparison with current levels (e.g. Thompson et al. 1992), or that DNA could be extracted from them (Houde and Braun 1988, Ellegren 1991, Leeton et al. 1993, Houde et al. in press). They could not have anticipated that rates of phenotypic change could be measured over such a short time-span as a century. Who could have known that a 14-year study designed to analyse seabird diets and moults by collecting specimens would produce the only evidence for increasing consumption of plastic pollutants by seabirds (Moser and Lee 1992) or that the same study would provide critical data for preventing offshore oil-drilling in the area (Lee and Socci 1989)? Who could have predicted the vital role that museum specimens can play in elucidating risks of the hantavirus to humans (Baker 1994)?

Therefore, those who believe that they know the limits of the research value of specimens lack historical perspective. Unless specimens continue to be col- 
lected, the current decades will be viewed as a dark age of scientific history, the time when scientists were unable to make permanent records of biodiversity because of opposition to scientific collecting.

\section{Specimens and conservation}

How can specimen data aid conservation? Sound conservation decisions must be based on the biology of the bird species in question. The volume of such information that can be extracted from collections of modern specimens is impressive, particularly information critical to conservation efforts such as distribution, diet, timing of breeding, ageing and sexing criteria, moult, and, for species from poorly known regions, habitat, and seasonal and elevational movements. Indeed, conservation biologists are among the most frequent users of specimen data, particularly from North American museums. For example, Collar et al. (1992) used specimen data on distribution, diet, timing of breeding, etc., gathered from more than 60 museums to assess former and current status of threatened birds in the Americas.

An example particularly appropriate for this volume that would apply to many tropical bird species derives from Ted Parker's 1989 visit to Parque Nacional Amboró, depto. Santa Cruz, Bolivia. There, he found the Bolivian Recurvebill Simoxenops striatus, known previously from fewer than five specimens from deptos. La Paz and Cochabamba and not seen since the 1930s, owing largely to lack of fieldwork in the region (Parker et al. 1992). Indeed, at least one ornithologist (Vaurie 1980: 253) was sceptical that the species was valid. A small series of specimens could demonstrate whether the Amboró population, c. $200 \mathrm{~km}$ south-east of the nearest previous localities, represents a population endemic to depto. Santa Cruz that might differ from other populations in size, plumage coloration, soft part coloration, or degree of sexual dimorphism. Because the topography of the Andes isolates many bird populations, such differentiation is a reasonable possibility. The tissue samples from this and other populations would also allow determination of whether Amboró populations were differentiated at the genetic level, even if no phenotypic differences were detected in the study skins. The presence of genetically differentiated populations in Amboró of a species with an already tiny geographic range would increase the biological importance of the park. Data on genetic variation would also permit an assessment of the degree of inbreeding in the population, which might have implications for the viability of the population (Allendorf and Leary 1986, Jiménez et al. 1994; but see Simberloff 1988). The additional specimen data on diet, moult, reproductive condition, and fat would provide the first such information on the biology of the species (see below for reasons why such data from released birds are inferior). At present no specimen of Simoxenops striatus exists in the world's tissue, fluid-preserved, egg, or skeleton collections (Wood et al. 1982, Kiff and Hough 1985, Wood and Schnell 1986) and the juvenal and immature plumages are unknown (Vaurie 1980), so studies of this species's genetic relationships or morphology are not possible.

The importance of new specimen material is not restricted to little-known tropical birds. For example, biochemical analysis of recent samples of a population of Grey-cheeked Thrush treated as a subspecies (Catharus minimus bicknelli) 
since its original description more than a century ago provided critical support for the hypothesis that this population is not freely interbreeding with other populations of $C$. minimus and that its recognition as a full species is consistent with levels of genetic differentiation found in other sibling species of bird (Ouellet 1993). Bicknell's Thrush C. bicknelli breeds only in a limited area of New England and extreme south-eastern Canada, adjacent to regions of extremely high human population density, and to small areas of montane scrub, at least in the southern portion of its breeding range. The winter range is poorly known, but evidently is restricted to portions of the Greater Antilles, perhaps primarily Hispaniola (the Haitian portions of which are among the most severely degraded environments in the Western Hemisphere). Thus, a study made possible by modern specimens has revealed a previously unrecognized but valid species with a precariously small, ecologically threatened winter range. Importantly, the breeding range of $C$. bicknelli is not in some remote region but in perhaps the best-known part of the continent in terms of ornithology.

Another example of the importance of continued collecting to conservation efforts concerns North American red crossbills. Current taxonomic treatments recognize only one species, the Red Crossbill Loxia curvirostra, found throughout most North American pine forests. However, recent detailed analyses (Groth 1993) of flight calls, mated pairs, morphometrics, and genetics, which could not have been done without collecting new specimens, have revealed that North America has at least seven and probably more species of red crossbills, each probably associated with a particular conifer species or suite of species (Benkman 1993a). Such resource specialization makes each crossbill species vulnerable to alteration of that resource, as is happening on massive scales by logging of conifer forests all across North America (Benkman 1993b). When red crossbills were considered to be one widespread species, conservationists paid little attention to the effects of forestry practices on "the" Red Crossbill, and if regional declines were noted (e.g. Benkman 1993c), they received no formal attention from conservation agencies. Recognizing that these regional populations and subspecies are probably species means that their populations must be monitored closely. For example, the species endemic to Newfoundland has declined dramatically with the introduction of a species of squirrel that feeds on the same cones (Benkman 1989), and many other crossbill species may also be at risk (Benkman 1993b). Only through a systematic research programme involving the collecting of numerous specimens and their associated vocal repertoires was this remarkable story unveiled.

More generally, because "species" is the taxonomic category characteristically used in determining conservation priorities, the analysis of modern specimens is crucial for evaluating species-level classifications. Analyses of recently available genetic material (e.g. Johnson and Zink 1983, 1985, Stevenson et al. 1983, Johnson and Johnson 1985, Johnson and Marten 1988, Zink 1988, 1994, Zink and Dittmann 1991, Groth 1993, Seutin et al. 1993) or even newly available study skins or anatomical specimens (e.g. Stiles 1981, 1983a, Graves 1982, Payne 1982, Pierpont and Fitzpatrick 1983, Remsen 1984, Silva 1991, Olson 1994) have produced numerous changes in species-level taxonomy. The overall conclusion that must be drawn from these studies is that species limits of birds, even in well-studied areas, often have been drawn too broadly, particularly by those 
who have assumed that the presence of a few intermediate individuals in parapatric situations represents "free interbreeding" and then extrapolated this reasoning to allopatric populations, especially on islands. The empirical results of the studies above imply that the true number of bird species in the world, regardless of species definition used, is substantially underestimated by current taxonomy. Recent results of studies of continental populations (as cited above) strongly suggest that much less differentiation is required for reproductive isolation than had been previously thought. By extrapolation, therefore, it seems likely that many island populations of birds currently considered to be only subspecies of widespread species should be classified as separate biological species. Because insular bird populations are particularly vulnerable, they require disproportionate attention from conservationists.

Accurate knowledge of taxonomic relationships through study of scientific specimens is critical to captive breeding programmes. For example, the breeding programme designed to "reconstitute" the now extinct Dusky Seaside Sparrow Ammodramus maritimus nigrescens may have failed specifically because its closest relative was not used (Avise and Nelson 1992; but see Zink and Kale in press). A related use of specimens is for determining probable area of origin, through subspecies identification, of confiscated live birds, whose release into the most appropriate population is being planned.

Conservation efforts directed at establishing priorities for land acquisition depend on an accurate knowledge of the taxa present, which in many regions requires judicious collecting of specimens to determine or corroborate identification, especially at the subspecies level. Even Ted Parker, the world's expert in field identification of Neotropical birds (and a world leader in bird conservation), frequently collected specimens to confirm the accuracy of his identifications (e.g. Parker and Bailey 1991). Accurate distribution patterns, particularly patterns of endemism, are fundamental to evaluating areas for land acquisition (ICBP 1992). Use of older specimens may be the only way to reconstruct the avifaunal composition of the many regions where habitat alteration is so extensive that we have no other way of knowing what should occur there; see Collar et al. (1992) for examples.

An increasingly frequent use of museum specimens relevant to conservation is their application to forensic analyses and enforcement of wildlife laws. Proper identification and apprehension of illegally transported birds or bird parts depend on museum collections. The advent of molecular techniques permits identification of even tiny fragments of material and will allow identification at the population-level of resolution, provided of course that collections of tissue samples include the taxa in question and that these samples are referenced to voucher specimens so that the identifications can be corroborated. Currently, barely one-third of bird species and a much lower proportion of subspecies/ phylogenetic species are represented in the world's composite tissue collections. Therefore such assays are crippled by the absence of specimens.

To do justice to use of specimens in environmental toxicology would require a separate paper. Bird specimens have played an important role in monitoring environmental health, and will continue to do so. Egg collections in particular have been pivotal in monitoring pesticide contamination (see references in Risebrough 1986), and school-children are now taught the story of DDT, pelicans 
and peregrines, and egg-shell thinning. Frozen tissue collections are potentially even more important as records of historical and current levels of toxic substances in the environment.

Conservation of birds benefits immensely from bird illustrations in popular and technical books, which not only generate general interest in birds but facilitate their identification for surveys for assessing conservation status. These books, especially field guides, also greatly encourage ecotourism, which might provide sufficient economic justification for preserving natural habitats. These illustrations are based largely on museum specimens. Most artists who use museum collections find that gaps in age, gender, season, and geographic representation are frequent obstacles, even for common species, and that photographs are unacceptable as substitutes for models (H. D. Pratt, J. P. O'Neill, pers. comms.)

\section{Objections to collecting}

\section{Effect on bird populations}

Some people evidently believe that bird populations are permanently reduced by collecting (e.g. Kingsbury 1975). This objection, however, comes largely from those not familiar with population biology (as noted by Liversidge 1975, Colebrook-Robjent 1976).

Knowledge of the arithmetic of natural and human-caused mortality is essential to evaluating the impact of scientific collecting on bird populations. First, consider the number of birds taken by scientists. Over the last 15 years, I have spent a total of 14 months collecting birds in Bolivia. The goal of this general collecting (for reasons to be discussed below) has been to obtain as many specimens as possible of as many species as possible at a given locality. Such a goal might appear wanton, except for the fact that rarely are more than 10 specimens obtained of any one species. In Bolivia, a general collection of 1,000 specimens might include more than 300 species, or an average of only 3-4 specimens per species. For a few abundant species, series of more than 25 specimens have been obtained from single localities. For large species with low reproductive rates, such as hawks, herons, and cracids, seldom were more than one or two specimens collected.

Such small numbers of specimens have minimal if any impact on local bird populations. We detect almost no appreciable decrease in populations within the immediate area of our field operations (usually less than $0.5 \mathrm{~km}^{2}$ ). The only noticeable effects are restricted to territorial species of the forest undergrowth, which may become scarce temporarily near our lines of mist-nets; but even these species' populations are at normal densities only a hundred metres or so from the vicinity of our net lanes. In general, the populations of most types of bird are known to recover rapidly from population losses (Lack 1954).

On a regional scale, the impact of collecting is too small to measure or detect. A typical, common passerine species of tropical forest undergrowth occurs at a density of about 1 pair per 5 hectares (Terborgh et al. 1990). Therefore, $1 \mathrm{~km}^{2}$ of suitable habitat contains approximately 20 pairs of such a species, which is far more individuals than scientists can take of most species at a single locality. 
In good habitat, therefore, an area of only $10 \mathrm{~km}$ by $10 \mathrm{~km}$ may contain up to 2,000 pairs of a typical species, far more individuals than exist in all the world's collections combined for most tropical species after more than 150 years of scientific collecting. An area of 100 by $100 \mathrm{~km}$ would theoretically contain 200,000 pairs of any one species, or far more individuals than exist of all bird species combined in any but the three or four largest museums in the world. Those species that occur in densities much lower than 1 pair/5 ha are also those for which only a few can be collected even with effort, because their density is low.

An instructive way to look at potential impacts of collecting on populations is to examine population sizes at the national level. Bolivia, for example, is approximately $1,100,000 \mathrm{~km}^{2}$ in size. If a rare species is found in only $1 \%$ of this area and it occurs at the low density of only I pair per $\mathrm{km}^{2}$, this still represents 11,000 pairs of this rare species within Bolivia's boundaries alone. Obviously, this is far more individuals than have ever been or ever will be collected. A more typical species might occupy $10 \%$ of Bolivia and would occur in much higher densities, say 40 per $\mathrm{km}^{2}$, and therefore Bolivian populations alone would be approximately 4,400,000. Collecting 25 individuals of such a species would represent a temporary loss of $0.00057 \%$ of the Bolivian population alone. Some common species may be found in as much as $25 \%$ of Bolivian territory and occur in densities of at least $100 / \mathrm{km}^{2}$; therefore, populations of these species in Bolivia alone are at least $27,500,000$. If such species are found throughout Amazonia, their populations would be on the order of 500,000,000 to 1 billion.

Such calculations are also instructive for much smaller regions, for example Great Britain (c.244,000 $\mathrm{km}^{2}$ ) and other political units with territories of roughly 240,000 to $300,000 \mathrm{~km}^{2}$, e.g. Ecuador, Ghana, Italy, New Zealand, the Philippines, Uganda, and the states of Colorado (U.S.A.) and Victoria (Australia). If a rare species is found in only $1 \%$ of this area, and there is only I pair per $\mathrm{km}^{2}$, then there are still 2,440 pairs of this rare species within Great Britain's boundaries alone each year. Again, this is certainly far more individuals than have ever been or ever will be collected. A more typical species might occupy $10 \%$ of British territory and would occur in much higher densities, say 40 individuals per $\mathrm{km}^{2}$, and therefore British populations alone would be approximately 976,000 . Collecting 25 individuals of such a species would represent a temporary loss of $0.0026 \%$ to the British population.

The above arithmetic does not incorporate natural rates of reproduction and mortality. Most tropical passerines have two eggs per clutch and lay more than one clutch per year (Skutch 1985). Under conditions of stable population size, this means that such reproductive rates must also be accompanied by comparable mortality rates, which in tropical birds studied so far seem to be highest at the egg and nestling (Skutch 1985) and presumably first-year stages of life. Most analyses of adult mortality rates of tropical birds have produced estimates of $10-25 \%$. Therefore, in a population of $4,400,000$ at least 440,000 to $1,100,000$ adults will die each year from natural causes. Such numbers are much higher than the number of all specimens of all species combined in any but the three largest museums in the world.

For temperate latitude birds, reproductive and mortality rates are substantially higher (Cody 1971). Clutch sizes are $4-6$ and annual adult mortality rates are $40-60 \%$ for most small birds (and much higher for first-year birds). Thus for 
a population of 976,000 of a British passerine (see example above), roughly 488 , ooo will die each year, which is probably far more specimens of all British bird species than exist in the world combined. Even for an extremely rare passerine species, with say a population of 500 , about 250 will die every year from natural causes.

Some have expressed alarm that collecting specimens, particularly extralimital records, may prevent natural range expansions (Pyle 1993, Odin 1994). For example, Cruickshank (1961) worried that collecting of six specimens of Ashthroated Flycatcher Myiarchus cinerascens in Louisiana between 1943 and 1960 was playing a role in preventing this species from adding this state to its natural winter range: "By now this species may have been fairly well established as a winter visitor had it not been for the unnecessary collecting of every individual possible daring to appear in that state." Such worries stem from unrealistic views of the efficiency of detecting extralimital vagrants by both birders and scientists, and of the nature of colonization. The effort required to collect all potentially colonizing individuals in a region as large as, for example, southern Louisiana is beyond the combined resources of all North American museum scientists. Furthermore, once natural range expansions are under way, only massive intervention by humans could halt them. Even if the vanguard individuals were collected, the population pressure that drives such invasions would generate new colonists. The vast majority of species recorded as extralimitals in an area do not find that area suitable for colonization; otherwise, chances are extremely high that they would have already done so, either by long-distance random dispersal or by advancing kilometre by kilometre, given that they have had hundreds of thousands, perhaps millions, of years to have colonized that area. In the case of remote islands, where indeed the number of potential colonists is minute, the chances of a scientist collecting the very individuals that would have colonized successfully are vanishingly small. For example, the Hawaiian Islands have been colonized by landbirds only about eight times in their roughly 5-million-year existence; scientists have collected birds there for fewer than 100 of those years.

Overwhelming evidence indicates that natural mortality for most bird species in most years is density-dependent (Lack 1954, 1966, Gill 1995). Therefore, when a few individuals are collected by scientists, these are replaced by individuals that otherwise would have died without being recruited into the breeding population. No evidence exists that scientific collecting represents additive mortality. Mortality of most waterfowl due to hunting is non-additive (Burnham and Anderson 1984), even though hunters kill millions of ducks; so it is extremely unlikely that the few thousands of birds killed by scientists represent additive mortality. Bird populations are resilient to local, temporary reductions in numbers and quickly rebound to levels at which natural controls are in force. Otherwise, population extinction would have occurred long ago. Regulated collecting of specimens cannot damage populations of birds except for those very unusual situations in which the population is so small or so slowly reproducing that even the loss of a few individuals would risk population extinction. Such species or populations are universally considered endangered, it is illegal to collect them, and modern scientists themselves would object to collecting individuals from these fragile populations. 
Ironically, the same permit-granting agencies that place severe restrictions on the number of specimens that may be taken by scientists often authorize the taking of millions of game birds. For example, in the United States hunters are permitted to kill each year approximately 50 million Mourning Doves Zenaida macroura. Astonishingly, this number is roughly an order of magnitude more than all the specimens of birds that exist in the world's museums combined. Yet, year after year the Mourning Dove not only remains abundant but increases on a nearly continent-wide scale (Robbins et al. 1986). In contrast, museum scientists are typically permitted to collect only 2-4 Mourning Doves per year in most states (versus in Louisiana, for example, where each hunter has a daily bag limit of 15 for a 50-day season, or potentially, 750 birds). Winker et al. (1991) pointed out that in the state of Minnesota maximum effort and success by a single hunter would allow the taking (and eating or discarding) of more than 5,190 game birds per year, whereas the entire staff of a research museum had permits to take a combined total of only 120 individuals of the same set of species, despite the museum's commitment to preserve these bird specimens for study forever. Legal challenges to the scientific basis for such gross inequities should be considered by museums and scientific societies; permit-granting agencies should be forced to show what "management plan" indicates that some species can be killed for sport in enormous numbers, when no more than a few individuals of the same or other species can be taken for scientific reasons.

In many countries and states, the situation is even more ironic: the same permit-granting agencies that drastically restrict scientific collecting allow enormous tracts of native habitats to be logged, thereby destroying huge populations of birds (Diamond 1987). Clearance of a single square kilometre of tropical forest probably destroys more birds than are collected by any museum in most years. Minimum estimates of the rate of destruction of tropical forests are roughly $76,000 \mathrm{~km}^{2} / \mathrm{yr}$ (Myers 1986 and references therein). If bird density in these forests is roughly 1,900 birds $/ \mathrm{km}^{2}$ (Terborgh et al. 1990), then the world's population of tropical forest birds is lowered by approximately 144,400,000 birds/yr. This represents a yearly population loss just from tropical forest habitats equivalent to 16 times the number of specimens of all bird species that exist in the world's museums combined. Furthermore, collecting specimens only lowers populations temporarily and locally, whereas habitat destruction removes them permanently.

Mortality inflicted on birds by scientific collecting is immeasurably small relative to other human-caused mortality. In addition to habitat destruction discussed above, collisions with vehicles, glass windows, and communications towers cause millions of bird deaths annually in the United States. As many as 50,000 migrating birds have been killed at one airport ceilometer in a single night (Johnston 1955). Klem (1990) estimated that window collisions alone kill roughly 100 million to 1 billion birds annually in the United States alone. Domestic cats are also a huge source of mortality. Extrapolating from Churcher and Lawton's (1989) estimate of 20 million birds per year killed by British cats, Winker et al. (1991) estimated that cats kill more than 80 million birds/year in the U.S.A., and Walsberg's (1994) estimate was 638 million/year. Particularly stunning are the mortality estimates for long-lived seabirds caused by entanglement in fishing nets (e.g. Croxall et al. 1984, Atkins and Heneman 1987, and references therein); 
worldwide mortality is in the millions, with substantial negative impacts on some seabird populations. Millions of birds per year are also removed from natural populations for the cage-bird trade (Mulliken et al. 1992). Finally, and most shocking of all, recent estimates of mortality of European birds from hunting and trapping in the Mediterranean countries are roughly i billion/yr (Magnin 1991).

\section{Moral objections}

Some people object to the killing of any living thing on religious or moral grounds. Likewise, some people believe, for personal moral reasons, that it is wrong to kill birds, regardless of the effect on populations or any potential conservation benefit. Arguing over such moral positions with scientific logic is a useless exercise and outside the realm of this paper. But in American society, at least, positions based only on religious traditions are constitutionally prevented from being enacted into law (e.g. vegetarians have the right not to eat meat, but have no right to prevent others from doing so). Similarly, no scientist, for example, could force another person to kill birds. Scientists who collect specimens ask for a reciprocal degree of moral respect for debatable moral convictions. In particular, it is wholly inappropriate if such "moral" arguments are used by agencies charged with issuing scientific permits when these same agencies manage permits for sport hunting and fishing.

Although morality is not a proper subject for scientific debate, scientists can, and indeed ought, to expose the hypocrisy of their "moral" opponents. Many people seem not to recognize that most individual birds live for only a few years, and that most birds experience death in violent or unpleasant circumstances: predation, starvation, or disease. The reality of the natural world is that every year, billions of birds die across the planet from natural but painful causes. Most scientists, therefore, do not believe that it is "wrong" to sacrifice a few individuals, usually in the most humane way possible, for the purpose of gaining more knowledge that in turn will be applied to saving birds through scientifically sound conservation (Diamond 1987). Perhaps those opposed to collecting would not feel so strongly if they kept in mind two facts of bird demography: ( 1 ) only one or two of every too adult small birds seen five years ago are still alive today, and (2) a single bird-eating hawk that eats just one bird per day will consume 1,825 birds in five years, which for the majority of bird species is far more specimens than exist in all the world's museums combined.

Those who object to collecting on moral grounds often do not appreciate that they themselves kill birds directly or indirectly throughout their lives. Their own existence as a consumer of natural resources has a permanent and negative effect on bird populations. Anyone who uses or consumes materials produced by habitat-destroying industries, such as agriculture, forestry, energy production, and chemical production, has no moral basis to condemn scientific collecting. Anyone who believes it wrong to kill birds should live in houses without glass windows because these kill millions of birds every year. They should never drive or ride in motor vehicles because such conveniences directly kill millions of birds annually, and operation and construction of them sponsor industries that contribute to massive direct (e.g. oil spills) and indirect mortality 
of birds. They should never buy books, live in houses constructed with wood, or consume any other products of the timber industry, one of the deadliest enemies of forest bird populations. Otherwise, I regard opposition by such people to scientific collecting as hypocritical and a failure to distinguish direct from indirect effects of human actions (Remsen 1993).

If it is "moral" to drive a vehicle, to have glass windows in a house, or let a pet cat outside (see mortality estimates above), why is it "immoral" to collect a tiny fraction of a bird's population to gain knowledge that ultimately benefits the conservation of that species? The list of sources of significant, human-caused mortality (e.g. radio towers, barbed wire fences, power lines, lighthouses, airplanes, etc.) is nearly endless (Banks 1979a), yet these are not under attack for their immorality. The Washington Monument in Washington, D.C., kills more birds annually (at least 328/yr: Overing 1938) than do most scientists; should we therefore dismantle the Washington Monument? The number of birds killed by museum scientists each year is closer to that killed accidentally by fishing lines and lures (Nickell 1964, Sallee 1978, Bartel 1984), kite strings (Evrard 1985), bird-feeders (Brittingham and Temple 1988), livestock water tanks (Craig and Powers 1976, Chilgren 1979), or human-provided nest material (Fillmore and Titman 1977, Jackson 1981) than it is to the number killed by commonplace, daily human activities. To a bird, it makes no difference whether it was killed deliberately by a museum scientist or accidentally by a window, vehicle, fishing line, or kite string, regardless of the moral predilections of the perpetrator.

Paradoxically, many who oppose collecting birds on moral grounds often do not feel the same way about collecting other organisms, even of comparable size and complexity. Birds, because they are "pretty" or "cute", are perceived as "good", and therefore worthy of total protection. In contrast, other vertebrates of roughly equivalent body size to that of birds, and with equal or longer life-spans, such as fishes, snakes, lizards, rodents, and bats, are often perceived as "bad" or "unpleasant" and therefore are not afforded as much protection from scientists. Permit restrictions between "good" and "bad" animals often differ dramatically and illogically. Scientists are exasperated by such inconsistencies. For example, in California the only permit needed to collect up to four individuals of most salamander species is a fishing license (N. K. Johnson in litt.). I wonder whether those who oppose scientific collecting of birds also refrain from consuming tuna, swordfish, octopus, lobster, large crabs, abalone, and other large, long-lived wild animals.

\section{Don't we have enough specimens already?}

The world's museums house no more than nine million specimens of birds (Goodman and Lanyon 1994). Although this might seem to be an enormous number and more than adequate for all future research projects, those who use museum collections for research know otherwise (Stiles 1983b, Goodman and Lanyon 1994). After these nine million specimens are distributed among the 9,000 species of birds and among the approximately 180 countries of the world, the number of specimens that can be applied to a particular project is reduced drastically. The vast majority of these specimens were collected before 1950, and most of these have minimal data beyond locality and date, because collectors of 
earlier eras did not realize the importance of other specimen data. Worse, hundreds of thousands of nineteenth-century specimens, mainly taken by professional collectors who were not scientists, are labelled with nothing more than such ambiguous or faulty localities as "Bogotá", "Cayenne", "Atlantic Ocean", or "India", and are thus nearly useless for modern research. Seasonal biases in sampling further limit analyses. Finally, many older specimens were so poorly prepared that their use for any purpose is limited.

The percentage of existing museum specimens accompanied by detailed data that can be applied to questions of relevance to modern conservation efforts actually is frighteningly low (Stiles 1983b). For example, Remsen and Parker (1990) attempted to analyse data from specimen labels to determine when and where the Azure Gallinule Porphyrula flavirostris reproduces, when it migrates, and what it eats. A search of most of the world's collections of South American birds yielded only 143 specimens, not a large sample but one that could have answered these questions. Only 123 were sexed specimens with usable locality data. More seriously, only $12(8 \%)$ labels included gonad sizes for assessing reproductive condition (and thus assurances that the specimen was sexed correctly), only two (1.4\%) included fat level, and only one listed stomach contents. Marantz and Remsen (1991) found that most existing specimens of the Slaty Elaenia Elaenia strepera were of minimal use for documenting the annual cycle. The distribution of dates of specimens at temperate latitudes is often highly skewed towards spring and in many cases summer specimens. Such gaps may conceal important information. For example, Dittmann et al. (ms) examined of a series of recently collected fresh fall and early winter specimens of the eastern Solitary Vireo Vireo s. solitarius and re-established that this taxon is sexually dimorphic in plumage, a feature that had escaped notice for more than a century, mainly because reliably sexed fall and winter specimens were scarce. For several abundant passerines of the western United States, S. Rohwer (in litt.) and his students have located only 3-15 specimens in moult (apparently because many western species migrate to moulting stop-over sites in the southwestern U.S.A. and northern Mexico, where collectors have rarely worked in late summer). In general, specimens in moult of even the most common birds are scarce in collections, making it extremely difficult to quantify the timing and sequence of this important and under-studied life-history parameter (Thompson and Leu 1994), which in turn sheds light on timing of reproduction and migration. For birds of tropical latitudes, specimen dates are typically highly skewed towards the Northern Hemisphere summer, when most "northern" biologists at academic institutions can do fieldwork. Storer (1988) pointed out that modern specimens of large birds in general are so scarce that research on their basic biology is hindered. If these examples are typical, and there is no reason to believe otherwise (Parkes 1963), then the existing specimens in the world's museums are tragically inadequate for addressing questions about the biology of our birds. This basic biology is still the foundation for building sound conservation strategies.

The inadequacy of the world's anatomical collections (skeletons and fluidpreserved material) is well documented. Despite their critical roles in the study of morphology, anatomy, and systematics, anatomical specimens exist for only about two-thirds of the world's 9,100 bird species, and the long series of anatom- 
ical specimens needed for many kinds of analyses are available for only a few species (Zusi et al. 1982). Many species are represented by only one or two specimens, many of substandard condition because of poor preparation or curation. An inventory at the level of distinctive subspecies would reveal even greater gaps. Gaps in representation of anatomical specimens are particularly large for species in most South American countries, sub-Saharan Africa, India, Burma, and New Guinea (Jenkinson and Wood 1985). Even at temperate latitudes, the skeletal samples for many species are dominated by specimens from areas outside the breeding range (e.g. tower- and window-killed migrants), which cannot be used for analyses of geographic variation in skeletal morphology. For example, Guillemots Uria aalge are represented by over 1,000 specimens in skeletal collections (Wood and Schnell 1986), yet most of these are non-breeding birds found dead on beaches; in a recent effort to use skeletal morphometrics to map oil-killed Guillemots from the west coast of North America to breeding areas of origin, S. Rohwer (in litt.) and his colleagues found only a single breeding-season specimen from all of British Columbia. For many other species, skeletal samples are dominated by aviary or zoo specimens; these are of limited use in any but gross interspecific comparisons, and they may have skeletal or muscle abnormalities due to diet or confinement in captivity. Thus, even the large numbers of skeletal specimens reported for some common species are of limited use for many analyses of intraspecific variation.

In spite of considerable interest in egg collecting during the nineteenth century, the world inventory of eggs (Kiff and Hough 1985) shows dramatic gaps. For example, egg sets are available for only one of 17 species of jacamar (Galbulidae), 30 of 231 antbirds (Formicariidae), six of 61 cotingas (Cotingidae), and 16 of 58 flowerpeckers (Dicaeidae).

A worldwide inventory of tissue samples of birds does not yet exist. The collection housed at the Museum of Natural Science, Louisiana State University, is by far the world's largest. After 15 years of intensive efforts, samples of approximately 2,300 species are represented. We doubt that more than 1,000 additional species are represented in the few other tissue collections in the world. Thus, the proportion of the world's avifauna represented by such samples is probably less than $30 \%$. At the level of differentiated populations (subspecies/phylogenetic species), representation is considerably less complete. No biologist would dispute the obvious value of analyses of molecular variation in birds, yet these analyses are almost always hindered or crippled by lack of material. Furthermore, this material does not last forever and is depleted when analysed, requiring replenishment. With the steady flow of new molecular techniques for genetic analyses, even material analysed previously must be replaced for future analyses; collectors must be more conscientious about saving tissues whenever possible.

Sadly, in some cases the destruction rate of bird specimens may be faster than the rate of addition. Although the importance of scientific collections has never been greater, natural history museums throughout the world are losing specimens through lack of curation, usually due to financial problems (e.g. Seymour 1994). Several bird collections have been decimated or destroyed by absence of care (e.g. Rylander 1967), and the recent loss of curatorial positions in ornithology at some important museums (e.g. British Museum of Natural 
History, San Diego Natural History Museum, National Museum of Canada) represents the first step towards increasing neglect once collections are devalued by administrative policies or financial constraints.

In summary, the inadequacies of the world's museum collections of birds are glaring and numerous. Anyone who seriously asks whether we already have enough specimens reveals their lack of awareness of the kinds of studies for which specimens are used, and on which much of our knowledge of birds is based. However, it must also be emphasized that the purpose of scientific collecting is not simply to fill these gaps, as if the world's collections were some sort of scientific "stamp collection" with a finite endpoint beyond which no more specimens are needed. Filling such gaps only represents the bare minimum that would then permit comprehensive comparative analyses. Future needs of collections, however, are dynamic and are not limited to gap-filling.

\section{Can't the data be obtained without harming the birds?}

Examination of live birds in the hand does indeed yield some of the same data as specimens, and ornithologists, including those who collect specimens, have pioneered imaginative methods for studying birds closely without sacrificing them. An experienced researcher can take some of the same linear measurements taken from study skins and examine plumage for moult, observe soft-part colours, determine fat levels, and record body weight and skull ossification. Although the danger to the bird is increased, emetics or stomach-flushing can be used to obtain stomach samples, laparotomies performed by some experts to examine the reproductive tract, and some blood, feather pulp, and small bits of muscle extracted for biochemical analysis. Ptilochronology (Grubb 1989) allows detection of certain energetic histories and growth rates, without harming the bird other than by making it grow a new tail feather. Why, therefore, does the need ever arise to take the bird's life (McGeehan 1994)?

Although such physical examinations and measurements of live birds provide valuable information without destroying the bird (and are particularly valuable if the individual can be marked for subsequent recognition, such as by banding), such studies have severe limitations. Foremost is the philosophical and methodological point of lack of repeatability or means of independent verification (Stiles 1983b), a cornerstone of the scientific method. Properly curated specimens survive indefinitely, permitting reassessment of most data by independent investigators, as well as detailed, future assessment of phenotypic characters. Voucher specimens are widely recognized as fundamental to scientific accuracy. Confusion among blood or tissue samples that lack vouchers can lead to critical errors and erroneous results (see Houde et al. in press). In my experience, errors in in-the-hand identification of specimens at the species level in the field are frequent, even by the most skilled and experienced scientists. Such errors are not detected until the specimens are deposited in the collection and properly identified. Thus, field identification at the subspecies level is even more precarious and should seldom be attempted. Therefore, in my opinion, tissue samples without voucher specimens have minimal scientific value. Absence of vouchers is acceptable only when studies involve rare or endangered species. Finally, specimens collected for one project are often of use in many 
additional, often unanticipated studies, in contrast to samples or data taken from released birds, which are of more limited value. Additional drawbacks of studies of captured-and-released birds are:

1. Such studies are feasible only for those birds that can be easily captured. Species found mainly in the canopy, air, on the ground or water, or in open areas, and thus mist-netted infrequently or with great difficulty, often cannot be captured alive in sufficient numbers.

2. Such studies cannot involve analyses of geographic variation in plumage, which require careful, repeated side-by-side comparisons of large samples of specimens, including substantial numbers from single localities to assess individual variation (Stiles $1983 \mathrm{~b}$ ).

3. Obviously, the skeleton and internal organs cannot be examined in detail; birds intended for anatomical analyses cannot be released.

4. In many species, gender cannot be determined other than by inspection of gonads; even in those cases in which there are mensural differences between the sexes, sophisticated morphometric analyses usually fail to distinguish the sexes with 100\% reliability (e.g. Gruys and Hannon 1993, Winker et al. 1994). Measurements of the cloacal area for gender determination are useful only during the breeding season and are seldom $100 \%$ accurate (Boersma and Davies 1987). Likewise, biochemical techniques do not always allow accurate sex determination (e.g. Tiersch and Mumme 1993) and require detailed laboratory analyses. Laparotomies can be performed reliably and safely only by those with extensive experience with this technique. Although most data indicate no subsequent effect of laparotomy on survival, birds sometimes die during the procedure itself (Ketterson and Nolan 1986) or suffer injury and weight loss (Berthold 1969, Rohwer 1975, Fiala 1979), despite all possible precautions. Laparoscopy (Greenwood 1983) allows direct examination of gonads (unless occluded by fat) with a small puncture and insertion of optic cable, and the mortality rate is below $1 \%$; however, it is expensive $(\$ 3$, ooo for equipment for small birds) and requires a power source (Richner 1989).

5. Accurate determination of moult of contour feathers is virtually impossible in a hand-held, living bird, and determination of age classes in the primaries of many large birds requires extensive comparisons of specimens (Langston and Rohwer 1995, S. Rohwer pers. comm.).

6. Fat levels as ascertained by inspection of the furcular area are usually much less reliable than those obtained by inspection of the entire body, as is done when a specimen is prepared. The degree of fat deposition in various parts of the body varies among taxa (D. L. Dittmann, S. W. Cardiff and K. Winker, pers. comm.). Measurement of body fat by non-invasive techniques (e.g. Walsberg 1988, Roby 1991) requires laboratory equipment not amenable to most field research.

7. Determination of degree of skull ossification is not as accurate as that performed on a dissected specimen.

8. The bursa of Fabricius, an excellent indicator of age, particularly for species without age differences in skull ossification or plumage (e.g. Broughton 
1994), can be examined only with great difficulty in the field in small-bodied live birds.

9. Presence of most internal parasites cannot be assessed in a living bird.

10. Measurements of living birds differ from those of dried specimens of the same species, making comparisons difficult (e.g. Greenwood 1979, Fjeldså 1980, Green 1980, Knox 1980, Herremans 1985, Winker 1993).

11. The small number of protein loci available in feather pulp or blood samples make their use limited (Marsden and May 1984, Mumme et al. 1985); even bits of muscle tissue do not contain all the loci frequently used in protein electrophoresis, some of which may be critical for the analysis or for comparisons with other studies.

12. The volume of blood or muscle that can be taken without harming a small bird is often so small that it limits the number of analyses possible, leaving little room for inevitable laboratory mistakes or freezer failures, or for subsequent analyses.

13. Analysis of levels of toxic chemicals accumulated in the liver, kidney, or brain cannot be performed on a living bird. Such analyses are fundamental to determining levels of contaminants in the environment.

Technological advances will certainly obviate a few of these problems; however, unless the cost of application of such advances is low, their usefulness to fieldwork will be limited, particularly in the developing countries of the world, where studies are most needed, and even then other limitations will remain.

Although the gathering of data from living birds is often touted as a nondestructive technique, such is not the case. The stress of capturing and holding an individual bird may itself cause mortality (Walkinshaw 1942, Recher et al. 1985, Poulin et al. 1994, McGowan and Caffrey 1994) or have negative postrelease effects on the individual, particularly during the breeding season (Burtt and Tuttle 1983, Colwell et al. 1988). Emetics and tissue extraction may increase the likelihood of certain negative effects (Zach and Falls 1976, Lederer 1978, Frederick 1986, Westneat et al. 1986; but see also Stangel 1986, Westneat 1986). In general, anyone who has witnessed a complete examination of a hand-held living bird, many of which are often kept for an hour or more before examination, must wonder about the fate of a bird thus traumatized in a world where annual adult mortality rates are already $10-60 \%$. Even if not fatal, handling may cause desertion of the study area (e.g. Poulin et al. 1994). The ringing of birds is also associated with increased rates of mortality or injury (Marion and Shamis 1977 and references therein, C. A. Munn unpubl. data); even if this mortality rate is very low, the huge number of birds ringed annually (millions worldwide) means that the annual mortality caused by this activity far exceeds annual mortality due to scientific collecting. For example, if the percentage of birds killed by ringing is only $0.5 \%$, then 3,937 of the 787,320 birds ringed in 1991 in Britain and Ireland (British Trust for Ornithology 1993) died as a result. Even the colour of the rings used may have unforeseen deleterious effects (Hagan and Reed 1988). Studies involving any manipulation, disturbance, or marking of nests can affect reproductive performance (e.g. Hunt 1972, Picozzi 1975, Robert and Ralph 1975. Fetterolf 1983, Hamilton and Martin 1985, Westmoreland and Best 1985, 
Major 1989). Even studies involving only observations may be detrimental to the birds involved (e.g. Ollason and Dunnet 1980 and references therein). Many research projects that address conservation questions do so by analysing demography of bird populations; such studies often require capturing and marking of birds (e.g. Porneluzi et al. 1993), monitoring of nests (e.g. Robinson 1992), weighing and banding of nestlings (Haig and Oring 1988), or combinations of all of these (e.g. Woolfenden and Fitzpatrick 1991). Should such studies be eliminated because they risk harming their study organisms? Is the mortality that results somehow "better" because it is inadvertent? Most would agree that the benefits to conservation are worth the inevitable losses. The point is that scientific collecting is just as beneficial because of the knowledge that it produces, and should not only be allowed but encouraged alongside "nondestructive" means of gathering information. In contrast to studies based on released birds, specimen-based research produces raw material that can be checked, examined, verified, compared or otherwise studied again as new ideas, hypotheses, and research needs arise.

Some people maintain that photographs can be substituted for actual specimens for corroboration of identification or even the study of geographic variation in coloration. Although photographs can corroborate identification of most birds at the species level, in many cases they cannot: the photos may not reveal the critical characters or the film development process may distort colour shades. Because most subspecies-level identifications depend on subtle shades or direct comparisons with specimens, subspecies identifications can rarely be corroborated by photographs (Stiles 1983b). Furthermore, comparisons between photographs taken under different conditions (birds in different postures and angles, lighting conditions, exposure, and kind and quality of film, camera and lens, as well as photographers of differing skills) are problematic. Finally, even if a photograph is maintained under high-tech, state-of-the-art methods, it cannot be ruled out that the raw data - the photograph itself - will change colour through time.

\section{Collecting specimens "sets a bad example"}

Some believe that allowing animals to be collected by scientists sets a bad example, especially in developing countries, where the focus should be on preserving animal life, not killing it. Some people apparently regard the scientific collecting of bird specimens as directly conflicting with the environmentalist attitudes and goals that they are trying to promote in developing countries. This "conflict", however, exists primarily for those from wealthy urbanized societies who have minimal direct experience with the reality of the natural world. Many "primitive" societies that depend on hunting for part of their food respect, revere, and occasionally deify their vertebrate prey. Many modern hunter-sportsmen also have much respect for and interest in the animals they hunt, and hunters have aided conservation greatly by providing economic incentives and direct funding for conserving millions of hectares, particularly wetlands, that benefit all wildlife. Some opponents of hunting believe that hunters, or even those that support them, are not "real" conservationists. For example, when the editor of British Birds pointed out that British birds benefited 
greatly from the habitat set aside for hunting (Sharrock 1986), one response (Moyser 1987) was that because Sharrock thought hunting should continue, he was not a "true conservationist." Thus, once again, many who are opposed to hunting and collecting have difficulty identifying the critical units of concern, namely habitat and the population it supports, from their concerns over the welfare of individual animals. This failure will have long-term negative consequences for conservation in developing countries, where the economic value of controlled harvests of animals may be the only leverage for their conservation (e.g. Baskin 1994). Opposition to harvests of individual animals solely for sentimental reasons may even doom real conservation efforts to maintain those animals' populations, because it ignores the real needs of struggling economies.

\section{Removal of specimens depletes a country's national heritage}

Removal of unique archaeological, paleontological, and anthropological specimens from a country by scientific collectors has stirred much controversy. Authorities from countries of origin are justifiably concerned that such unique, irreplaceable items are part of a country's cultural and scientific heritage and should not be removed. Unfortunately, permits for biologists working with living plants and animals have been caught up in the controversy and in some cases have been severely restricted for the same reasons. However, archaeological, paleontological, and anthropological specimens differ fundamentally from biological specimens because the former represent finite resources. In other words, museum specimens in the fields of archaeology and paleontology represent irreplaceable, unique objects, and many of those in anthropology are no longer being made by their cultures. In contrast, biological specimens are samples of dynamic, self-renewing populations. Except for some critically endangered species and populations, removing a few specimens does not deplete the resource (see section "Effect on bird populations" above). In fact, such renewable resources should be sampled to enhance the scientific knowledge that is part of a country's national heritage.

\section{Misconceptions concerning museum scientists}

Some opposed to collecting do not realize (e.g. Beane 1991) that museum scientists are typically also conservationists in practice or in spirit, and that most find the killing of birds necessary but distasteful. Most modern museum scientists have life-long interests in birds that would prohibit them from killing birds if they thought that this activity would not benefit the study of birds, or if they suspected that collecting specimens permanently damaged bird populations. In fact, if museum scientists did not believe deeply in the value of specimens, then they would not endure the bureaucratic and logistic troubles involved in collecting. Their commitment to continued collecting in the face of numerous obstacles should signal to others that these scientists know that specimens have tremendous biological value.

Beane (1991) expressed another misconception: "Ornithologists are measured by the numbers of birds they have collected." In fact, the job descriptions of museum scientists do not contain clauses such as "must collect specimens", nor 
are museum scientists rewarded in any direct way for the number of specimens collected. On the contrary, promotions and salary raises of museum researchers are typically based primarily on the quality and quantity of publications and grants, which may bear little or no relationship to collecting activity. If collecting of specimens were banned, then the research programmes of museum scientists would simply shift to different areas; their defence of scientific collecting has nothing to do with "saving their jobs". Contrary to the propaganda of some anti-collectors (e.g. McGeehan 1994), all museum scientists are interested in living birds, not just specimens, and almost all have active research projects involving vocalizations, behaviour, ecology, and other aspects of the biology of live birds. In fact, most museum-based projects inspire further work with living birds. Many influential conservationists, from Theodore Roosevelt to Theodore Parker, collected and continue to collect scientific specimens. Parker, for example, made use of or direct reference to scientific specimens in 41 of his 63 technical publications.

\section{Recommendations for granting collecting permits}

Scientists, conservation agencies, and governments should share the common goal of protection of populations and habitats, not individual birds. Because scientific collecting has no measurable impact on the vast majority of bird populations, and because scientific specimens represent an important source of information on bird biology and conservation, permit-granting agencies should encourage scientific collecting. Below I make recommendations for making regulations reasonable and scientifically sound while still maintaining control and monitoring scientific collecting.

\section{Numbers of specimens}

Scientific analyses depend on samples sufficiently large to permit statistical comparisons. Because levels of significance are traditionally (albeit arbitrarily) set at 0.05 ( 1 in 20 chance of being wrong), a sample size of 20 individuals (per age-sex class) from a locality (as defined below) might be considered a reasonable lower limit for most studies; however, more than 30 are typically needed to get stable estimates of means (Baker 1985). Unless the species were restricted to an isolated pocket of habitat, a sample of more than 20 specimens would not harm the populations of small or medium-sized bird species (say $<150 \mathrm{~g}$ body mass). As stated earlier, however, samples of this size can rarely be obtained for any one species at a collecting site, but scientists should be allowed a quota of at least this size per locality. For some very common species that are also of special interest because of strong differences between gender and age classes or pronounced individual variation, larger sample sizes would be needed for statistical analysis. For such common species, samples of more than 20 can be justified. Local populations of larger species, which are usually in much lower densities (or smaller species with unusually low densities), might be negatively affected, but only temporarily, within several $\mathrm{km}^{2}$ around a field site by collecting a sample of more than 20 . However, samples of more than six individuals of large $\left(>_{15} \mathrm{~g}\right)$ species are seldom taken by general collecting; researchers working 
with such species are forced to combine data from several localities or time periods. In general, the time required for field preparation of specimens with the full complement of modern data automatically limits the numbers of specimens that can be collected to levels below such sample sizes.

My general recommendations for the minimum limits on numbers of specimens that can be taken per collecting locality (approximately $1 \mathrm{~km}^{2}$ ) are at least: (a) 25 individuals for species with body size $<100 \mathrm{~g}$, (b) 15 individuals for species with body size $100-250 \mathrm{~g}$, (c) six individuals for those species $>250 \mathrm{~g}$, and (d) four individuals per species for species whose populations are potentially sensitive, such as raptors and large galliforms. Certain projects involving a few abundant species may require more individuals than allowed within these general guidelines. In such cases, the investigator should present a proposal that justifies why the exceptions should be permitted. In general, I emphasize that these limits should be treated as guidelines rather than fixed limits to allow flexibility to accommodate special projects. For example, the number of individuals that may be collected should be reduced for studies of populations of small, isolated fragments of habitats in which over-collecting might drastically reduce a population.

If an area will be destroyed by deforestation or dam construction, and if efforts to save such areas are regarded as futile, then scientists should be permitted to take as many specimens as possible from such doomed areas. Most animals displaced by habitat destruction do not crowd themselves into adjacent surviving habitat for long, and most eventually perish. Because populations are usually not compressible, those few individuals that do colonize adjacent areas successfully in turn displace individuals already occupying those areas. Thus, scientists should be encouraged to salvage what they can before the destruction. Government agencies, scientists, and the enterprises responsible for the destruction should communicate to identify such doomed areas to facilitate sampling them. In fact, financial support for sampling, preparing, and long-term curation of collections from such doomed areas should be included as part of mitigation negotiations.

I strongly recommend that every permitting agency make crude calculations of the number of individuals of each species within their areas of jurisdiction. Using the methods outlined in the "Effect on bird populations" section above, it is fairly simple to make such calculations using an approximate density estimate (reasonable estimates of territory or home range size can often be obtained by comparisons with confamilial species of similar body size, habitat and foraging guild for which such data are available) multiplied by the percent of the area that contains suitable habitat. Annual adult mortality rate can also be estimated by extrapolating from data for similar species for which the rate is known. Those applying for permits should consider making such calculations to defend their request. In either case, even the most conservative estimates will usually show that the local bird population in question numbers in the tends or hundreds of thousands or millions.

Permit agencies should recognize that the number of bird specimens that a scientist can potentially collect, prepare, and curate, even if completely unregulated, is very small. The resources required to process and house specimens are so limiting that the magnitude of scientific collecting is largely self-regulated by 
built-in constraints. Permit-granting authorities that allow only tiny numbers of specimens to be collected in a given year undermine their own scientific credibility by signalling that they are unaware of the arithmetic of population biology. Given that billions of birds die every year from natural and human-induced causes, there is no rational reason why scientists should not be allowed to take an immeasurably small fraction of living bird populations. At least in this way their mortality provides benefits for bird species themselves by accumulation of data on their biology.

\section{Percent of specimens left in host country}

Deposition of representative specimens in an established museum in the host country is important for increasing the capacity of biologists in the host country to conduct specimen-based research. However, some countries have recently begun to require that as many as $50 \%$ of the specimens taken be left in the host country. Such high levels of "taxation" are unfair to scientists who obtain those kinds of specimens that are not taken in high numbers per species and that take substantial amounts of time to prepare. It may be relatively easy for some biologists, e.g. entomologists and botanists, to leave behind large numbers of specimens because (a) the time required to capture and prepare large numbers of specimens is relatively small, and (b) sample sizes that remain after the $50 \%$ is left behind are still large enough for research purposes. Other biologists may not require large sample sizes for their research, and thus leaving behind $50 \%$ does not affect their analyses (and botanists can often make many specimens from an individual plant). However, biologists working with birds, mammals, snakes, and other groups for which adequate sample sizes are difficult to obtain, and for which preparation time per specimen is $30-60+$ minutes, are greatly handicapped by such quotas. For those who make general collections of birds, the situation is worst of all. A complex local avifauna may contain more than 300 species, and if even as many as 1,000 specimens are taken from a single collecting locality, an average of only 3.3 specimens per species handicaps any meaningful analyses for many species. If this is further reduced by $50 \%$, then making a general collection is not really worth the effort or expense. Such high levels will drive away the very museum scientists whose presence will benefit the host country's efforts in studying biodiversity and in collaborating with or training biologists of the host country. Indeed, the quota policies of several countries have virtually stopped specimen-based research there. This, of course, is counterproductive because they now receive no specimens at all from visiting biologists.

On the other hand, it is not fair to host countries if visiting scientists do not deposit representative specimens with host-country institutions. In my opinion, a fair share for the host country should vary upwards or downwards from approximately $20 \%$, depending on:

1. Other contributions to the host institution. In some cases, facilities for curation of specimens in the host country are inadequate. The host country should retain the flexibility to substitute other, more critical needs, such as curatorial supplies and equipment, in place of a portion of the specimen 
quota. Depositing specimens is fruitless if they cannot be curated properly, because they will eventually perish or be damaged. Also, contributions such as supplies, equipment, donated specimens to fill gaps in the host country's collection, and identification of specimens should be taken into account.

2. Quality and quantity of specimens. Visiting scientists will vary greatly in the quality, quantity, and kind of specimens they collected and prepared. Those visitors depositing data-rich, well-made specimens of unusual species or those collecting large numbers of specimens, especially those that are timeconsuming to prepare, should be encouraged to do so by imposing lower quotas on them.

3. Amount of training given to citizens of the host country. Students who accompany a collecting expedition receive extensive and intensive, free education from professionals on various topics in systematics, evolution, ecology and behaviour, as well as training in techniques of field biology, such as species identification and specimen preparation and care. The tuition costs of such an experience would be substantial. Training of this sort is unique and seldom available even to most North American or European students. The students will also naturally make long-lasting contacts with the visiting scientists that may have a profound positive impact on their careers.

Specimens deposited in the host country should be distributed as evenly as possible among the taxa collected. If the visiting scientist is accompanied by host-country scientists or students (which I feel strongly should be a requirement whenever qualified personnel are available), then the specimens of the host-country personnel will appropriately form the backbone of the material to be deposited in the host museum. Only if the fieldwork is a truly collaborative effort with roughly equal commitment of resources is the imposition of a $50 \%$ quota of specimens to be deposited in the host country reasonable. All such details should be in writing before fieldwork commences.

Overall I recommend that the distribution of specimens not be fixed at a certain level but be kept flexible so that it is fair to both host and visitor. I believe that if ornithologists from both sides discuss the individual situation freely, then a fair quota will be the result.

\section{Species composition}

Many agencies require that the number of specimens per species to be collected be specified in advance. Although this is a reasonable request for projects directed at a few target species, it is totally unfeasible for general collecting and inventory projects. If the species composition of the site to be visited could be determined in advance, then there would be no point in conducting an avifaunal survey (Liversidge 1975). In many cases, one can predict with some accuracy the species composition of a locality, but surprises occur frequently. Exploration is, by definition, exploration. Limiting permits to a list of species determined in advance defents the purpose of an inventory project and is a regulation that reveals how little knowledge permit-granting agencies have about scientific collecting.

I strongly recommend that permits be issued without requiring a predetermined list of species. If the agency follows the general recommendations for 
granting a certain number of specimens per species based on general body-size criteria as I have outlined above, then neither the agency nor the scientist wastes time with lengthy species lists. Only when the investigator seeks special permits for those species already on official lists of restricted species (threatened or endangered, supported by scientific rationale) should they be specified by the permit. It would be extremely helpful to visiting scientists to have a list of restricted species in advance of the permit application to avoid unnecessary delays. However, a discouraging trend in many countries, states and provinces is exponential growth of such lists of restricted species without scientific justification (e.g. Walsberg 1994); this is clearly "pseudoconservation".

\section{Deposition of specimens}

Specimens collected should be deposited in recognized museum collections with a history of stable and continued support, where they will then be available to other scientists once the investigator has finished the analyses. Some biologists have collected specimens solely to gather certain parts of the carcass, say stomach contents or blood samples, and have then discarded the carcasses. This represents a tragic loss of material that would be avoided by requiring scientists at least to offer their specimens to a museum.

\section{Processing applications}

Ironically, many permitting agencies grant hunting licences almost instantaneously, whereas permits to collect scientific specimens often take many months to process and often require pages of detailed justification from the applicant. The message this sends to the scientist only fuels cynicism about permit agencies: if someone wants to kill animals for sport, then no justification is required, but if the motive is to increase scientific knowledge of a species, then the request must be considered at length and in detail.

In the case of permit applications in foreign countries, officials in host countries are inevitably and naturally suspicious of scientists who propose to take anything out of the country. The message needs to be communicated more clearly that specimen collecting is a "win-win" bargain for the host country: the visiting scientists enhance the host country's scientific heritage by depositing specimens to document the biodiversity of the country, by interacting and collaborating with scientists and students in the host country, and by publishing data on the biology of the host country's avifauna. All they "take" from the country is a minute fraction of a renewable resource. Wise countries will use their renewable resources to encourage scientific collecting to enrich their national scientific heritage and infrastructure for assessing biodiversity.

\section{Closing remarks}

Museum scientists and conservationists are natural allies who should work together to achieve mutual goals rather than clash over minor, counterproductive issues such as if and how many specimens should be collected. Liversidge (1975), Diamond (1987), Finley $(1987,1988)$, and Walsberg (1993, 1994) pointed 
out that regulatory agencies that believe that conservation is served by restricting collecting permits are badly misinformed and are actually performing a disservice to their mission. Ironically, researchers from government agencies and private conservation groups are among the most frequent users of bird collections. Scientists have become embittered by governments that obstruct research or even persecute scientists for trivial violations (Diamond 1987, Graham 1992, Holden 1992, Walsberg 1993, 1994) while at the same time permitting rapid, permanent destruction of the very habitats the scientists wish to sample. Regulating agencies are often overly enthusiastic in restricting scientific collecting, which is one of the only types of mortality from which bird species (and research projects within the regulating agency) might derive benefit, while the same or sister agencies often permit and even encourage activities that are responsible for massive mortality in bird populations. Unfortunately, this generates frustration and cynicism among museum scientists, particularly because their taxes often pay the salaries of those making such decisions. Thus, some of conservation's most important allies become alienated. This is tragic, because in the face of massive loss of biodiversity, the need for cooperation between museum scientists, conservationists, and regulatory agencies has never been more critical.

\section{Acknowledgements}

This paper is dedicated to the person who inspired it, the late Ted Parker, who combined careers in bird conservation and specimen-based research. I am grateful to many people for comments on drafts of the manuscript or discussions of the topic, especially J. W. Fitzpatrick, H. D. Pratt, A. P. Capparella, N. J. Collar, G. F. Barrowclough, J. M. Bates, S. W. Cardiff, R. T. Chesser, M. CohnHaft, D. L. Dittmann, G. R. Graves, S. J. Hackett, N. K. Johnson, C. P. Kofron, A. W. Kratter, S. M. Lanyon, D. S. Lee, M. Marín A., D. C. Moyer, J. P. O'Neill, T. A. Parker III, J. D. Rising, M. B. Robbins, S. Rohwer, T. S. Schulenberg, F. H. Sheldon, T. S. Sillett, F. G. Stiles, R. W. Storer, D. M. Teixeira, D. A. Wiedenfeld, K. Winker, and R. M. Zink.

\section{References}

Alberch, P. (1985) Museum collections and the evolutionary study of growth and development. Pp.29-42 in E. H. Miller, ed. Museum collections: their roles and future in biological research. British Columbia Prov. Mus. Occ. Pap. No. 25.

Aldrich, J. W. and Weske, J. S. (1978) Origin and evolution of the eastern House Finch population. Auk 95: 528-536.

Allen, G. A. and Cannings, R. A. (1985) Museum collections and life-history studies. Pp.169-194 in E. H. Miller, ed. Museum collections: their roles and future in biological research. British Columbia Prov. Mus. Occ. Pap. No. 25.

Allendorf, F. W. and Leary, R. F. (1986) Heterozygosity and fitness in natural populations of birds and mammals. Pp.57-76 in M. Soulé, ed. Conservation biology. Sunderland, Massachusetts, U.S.A.: Sinauer Associates.

Arnold, N. (1991) Biological messages in a bottle. New Scientist (August): 25-27.

Atkins, N. and Heneman, B. (1987) The dangers of gill netting to seabirds. Amer. Birds 41: 1395-1403. 
Avise, J. C. and Nelson, W. S. (1992) Molecular genetic relationships of the extinct Dusky Seaside Sparrow. Science 243: 646-648.

Baker, A. J. (1985) Museum collections and the study of geographic variation. Pp.55-78 in E. H. Miller, ed. Museum collections: their roles and future in biological research. British Columbia Proz. Mus. Occ. Pap. No. 25.

Baker, A. J., Peck, M. K. and Goldsmith, M. A. (1990) Genetic and morphometric differentiation in introduced populations of Common Chaffinches (Fringilla coelebs) in New Zealand. Condor 92: 76-88.

Baker, R. J. (1994) Some thoughts on conservation, biodiversity, museums, molecular characters, systematics, and basic research. J. Mammalogy 75: 277-287.

Banks, R. C., ed. (1979a) Museum studies and wildlife management. Washington, D.C.: Smithsonian Institution Press.

Banks, R. C. (1979b) Human related mortality of birds in the United States. Washington, D.C.: Special Scientific Rep., Wildlife, No. 215, U.S. Fish and Wildlife Service.

Barlow, J. C. and Flood, N. J. (1983) Research collections in ornithology. Pp.37-54 in A. H. Brush and G. A. Clark, Jr., eds. Perspectives in ornithology. New York: Cambridge University Press.

Barrowclough, G. F. (1985) Museum collections and molecular systematics. Pp.43-54 in E. H. Miller, ed. Museum collections: their roles and future in biological research. British Columbia Prov. Mus. Occ. Pap. No. 25.

Bartel, K. E. (1984) Barn Swallow fatalities due to mono-filament fishline. North Amer. Bird Bander 9: 8 .

Baskin, Y. (1994) There's a new wildlife policy in Kenya: use it or lose it. Science 265: 733-734.

Beane, C. (1991) Ornithology versus aviculture. Bird Talk (June): 94-95.

Benkman, C. W. (1989) On the evolution and ecology of island populations of crossbills. Evolution 43: 1324-1330.

Benkman, C. W. (1993a) Adaptation to a single resource and the evolution of crossbill (Loxia) diversity. Ecol. Monogr. 63: 305-325.

Benkman, C. W. (1993b) Logging, conifers, and the conservation of crossbills. Consert Biol. $7: 473-479$.

Benkman, C. W. (1993c) The evolution, ecology, and decline of the Red Crossbill of Newfoundland. Amer. Birds 47: 225-229.

Berthold, P. (1969) Die Laparotomie bei Vögeln. Zool. Garten 37: 271-279.

Blem, C. R. (1975) Geographic variation in wing-loading of the House Sparrow. Wilson Bull. 87: 543-549.

Bock, W. J. (1985) Adaptive inference and museological research. Pp.123-138 in E. H. Miller, ed. Museum collections: their roles and future in biological research. British Columbia Prov. Mus. Occ. Pap. No. 25.

British Trust for Ornithology (1993) Service in ornithology: Annual Report 1992-93. JNCC Report No. 204. Peterborough, U.K.: Joint Nature Conservation Committee.

Brittingham, M. C. and Temple, S. A. (1988) Avian disease and winter bird feeding. Passenger Pigeon 50: 195-203.

Broughton, J. M. (1994) Size of the bursa of Fabricius in relation to gonad size and age class in Laysan and Black-footed albatrosses. Condor 96: 203-207.

Burnham, K. P. and Anderson, D. R. (1984) Tests of compensatory vs. additive hypotheses of mortality in Mallards. Ecology 65: 105-112.

Burns, K. J. (1993) Geographic variation in ontogeny of the Fox Sparrow. Condor 95: 652661 .

Burtt, E. H., Jr., and Tuttle, R. M. (1983) Effect on timing of banding on reproductive success of Tree Swallows. J. Field Orn. 54: 319-323.

Chapman, A. (in press) Annual cycles of four bird species in tropical West Africa. Tropical Zool. 
Chilgren, J. D. (1979) Drowning of grassland birds in stock tanks. Wilson Bull. 91: 345346.

Churcher, P. B. and Lawton, J. H. (1987) Predation by domestic cats in an English village. J. Zool. 212: 439-455.

Cody, M. L. (19871) Ecological aspects of reproduction. Pp.462-512 in D. S. Farner and J. R. King, eds. Avian Biology, 1. New York: Academic Press.

Colebrook-Robjent, J. F. R. (1976) Collecting capers. Bokmakierie 28: 45-46.

Collar, N. J., Gonzaga, L. P., Krabbe, N., Madroño Nieto, A., Naranjo, L. G., Parker, T. A., III, and Wege, D. C. (1992) Threatened birds of the Americas: the ICBP/IUCN Red Data Book. Third edition, part 2. Cambridge, U.K.: International Council for Bird Preservation.

Colwell, M. A., Gratto, C. L., Oring, L. W. and Fivizzani, A. J. (1988) Effects of blood sampling on shorebirds: injuries, return rates, and clutch desertions. Condor 90: 942945.

Craig, T. H. and Powers, L. H. (1976) Raptor mortality due to drowning in a livestock watering tank. Condor $78: 412$.

Croxall, J. P., Evans, P. G. H. and Schreiber, R. W. (1984) Status and conservation of the world's seabirds. Cambridge, U.K.: International Council for Bird Preservation (Techn. Publ. 2).

Cruickshank, A. D. (1961) Sixty-first Christmas Bird Count. Audubon Field Notes 15: 84-89.

Diamond, J. (1987) Justifiable killing of birds? Nature 330: 423.

Dittmann, D. L., Remsen, J. V., Jr., and Cardiff, S. W. (ms) Sexual differences in plumage color, and the prealternate molt in the Solitary Vireo Vireo s. solitarius. J. Field Orn. (submitted).

Dunne, P. (1988) Putting a dead bird to roost. Living Bird Q. (Spring): 38.

Ehrlich, P. R. and Wilson, E. O. (1991) Biodiversity studies: science and policy. Science 253: $758-762$.

Ellegren, H. (1991) DNA typing of museum birds. Nature 354: 113.

Fetterolf, P. M. (1983) Effects of investigator activity on Ring-billed Gull behavior and reproductive performance. Wilson Bull. 95: 23-41.

Fiala, K. (1979) A laparotomy technique for nestling birds. Bird-Banding 50: 366-367.

Fillmore, E. R. and Titman, R. D. (1977) Chipping Sparrow hanged. Canad. Field-Nat. 91: 69-70.

Finley, R. B., Jr. (1987) The value of research collections. BioScience 37: 92.

Finley, R. B., Jr. (1988) Guidelines for the management of scientific collecting permits. Wildl. Soc. Bull. 16: 75-79.

Fitzpatrick, J. W. (1985) The role of scientific collections in ecological morphology. Pp. 195-208 in E. H. Miller, ed. Museum collections: their roles and future in biological research. British Columbia Prov. Mus. Occ. Pap. No. 25.

Fjeldså, J. (1980) Post-mortem changes in measurements of grebes. Bull. Brit. Orn. Club 100: 151-154.

Fjeldså, J. (1987) Museum collections of birds - relevance and strategies for the future. Acta Regiae Soc. Sci. Litt. Gothoburgensis Zool. 14: 213-222.

Foster, M. S. (1975) The overlap of molting and breeding in some tropical birds. Condor 77: 304-314.

Foster, M. S. (1982) The research natural history museum: pertinent or passé? Biologist 64: 1-12.

Foster, M. S. and Cannell, P. F. (1990) Bird specimens and documentation: critical data for a critical resource. Condor 92: 277-283.

Frederick, P. C. (1986) Parental desertion of nestlings by White Ibis (Eudocimus albus) in response to muscle biopsy. J. Field Orn. 57: 168-170.

Gill, F. B. (1995) Ornithology. Second edition. New York: W. H. Freeman and Co. 
Goodman, S. M. and Lanyon, S. M. (1994) Scientific collecting. Conserv. Biol. 8: 314-315.

Graham, F., Jr. (1992) The ordeal of Nat Wheelwright. Amer. Birds 46: 374-377.

Graves, G. R. (1982) Speciation in the Carbonated Flower-piercer (Diglossa carbonaria) complex of the Andes. Condor 84: 1-14.

Graves, G. R. (1987) A cryptic new species of antpitta (Formicariidae: Grallaria) from the Peruvian Andes. Wilson Bull. 99: 313-321.

Graves, G. R. (1988) Phylloscartes lanyoni, a new species of bristle-tyrant (Tyrannidae) from the lower Cauca Valley of Colombia. Wilson Bull. 100: 529-534.

Graves, G. R. (1993) Relic of a lost world: a new species of sunangel (Trochilidae: Heliangelus) from "Bogotá". Auk 110: 1-8.

Green, G. H. (1980) Decrease in wing length of skins of Ringed Plover and Dunlin. Ringing and Migration 3: 27-28.

Greenwood, A. G. (1983) Avian sex determination by laparoscopy. Vet. Rec. 112: 105.

Greenwood, J. G. (1979) Post-mortem shrinkage of Dunlin Calidris alpina skins. Bull. Brit. Orn. Club 99: 143-145.

Groth, J. G. (1993) Evolutionary differentiation in morphology, vocalizations, and allozymes among nomadic sibling species in the North American Red Crossbill (Loxia curvirostra) complex. Univ. California Publ. Zool. 127: 1-143.

Grubb, T. C. (1989) Ptilochronology: feather growth bars as indicators of nutritional status. Auk 106: 314-320.

Gruys, R. C. and Hannon, S. J. (1993) Sex determination of hunter-killed and depredated Willow Ptarmigan using a discriminant analysis. J. Field Orn. 64: 11-17.

Hackett, S. J. and Rosenberg, K. V. (1990) Comparison of phenotypic and genetic differentiation in South American antwrens. Auk 107: 473-489.

Hagan, J. M. and Reed, J. M. (1988) Red color bands reduce fledging success in Redcockaded Woodpeckers. Auk 105: 498-503.

Haig, S. M. and Oring, L. W. (1988) Distribution and dispersal in the Piping Plover. Alik 105: 630-638.

Hamilton, G. D. and Martin, R. F. (1985) Investigator perturbation and reproduction of the Cliff Swallow. Auk 102: 167-170.

Herremans, M. (1985) Post-mortem changes in morphology and its relevance to biometrical studies. Bull. Brit. Orn. Club 105: 89-91.

Hobson, K. A. (1987) Use of stable-carbon isotope analysis to estimate marine and terrestrial protein content in gull diets. Canad. J. Zool. 65: 1210-1213.

Hobson, K. A. and Sealy, S. G. (199x) Marine protein contributions to the diet of Northern Saw-whet Owls on the Queen Charlotte Islands: a stable-isotope approach. Auk 108: $437-440$.

Holden, C., ed. (1992) Ornithologists feel beleaguered. Science 258: 396-397.

Houde, P. and Braun, M. J. (1988) Museum collections as a source of DNA for studies of avian phylogeny. Auk 105: 773-776.

Houde, P., Sheldon, F. H. and Kreitman, M. (in press) A comparison of solution and membrane-bound DNA $\times$ DNA hybridization, as used to infer phylogeny. J. Molecular Evol.

Hunt, G. L., Jr. (1972) Influence of food distribution and human disturbance on the reproductive success of Herring Gulls. Ecology 53: 1051-1061.

ICBP (1992) Putting biodiversity on the map: priority areas for global conservation. Cambridge, U.K.: International Council for Bird Preservation.

Jackson, J. A. (1981) Screech Owl caught in nylon Lichtenstein's Oriole nest. Southwest. Nat. 26: 214-215.

James, H. F., Zusi, R. L. and Olson, S. L. (1989) Dysmorodrepanis munroi (Fringillidae: Drepanidini), a valid genus and species of Hawaiian finch. Wilson Bull. 101: 159-179.

James, F. C. (1983) Environmental component of morphological differentiation in birds. Science 221: 184-186. 
Jenkinson, M. A. and Wood, D. S. (1985) Avian anatomical specimens: a geographic analysis of needs. Auk 102: 587-599.

Jiménez, J. A., Hughes, K. A., Alaks, G., Graham, L. and Lacy, R. C. (1994) An experimental study of inbreeding depression in natural habitat. Science 266: 271-273.

Johnson, N. K. and Johnson, C. B. (1985) Speciation in sapsuckers (Sphyrapicus): II. Sympatry, hybridization, and mate preference in S. ruber dagetti and S. nuchalis. Auk 102: $1-15$.

Johnson, N. K. and Marten, J. A. (1988) Evolutionary genetics of flycatchers. II. Differentiation in the Empidonax difficilis complex. Auk 105: 177-191.

Johnson, N. K. and Zink, R. M. (1983) Speciation in sapsuckers (Sphyrapicus): I. Genetic differentiation. Auk 10: $871-884$.

Johnson, N. K. and Zink, R. M. (1985) Genetic evidence for relationships among the Red-eyed, Yellow-green, and Chivi vireos. Wilson Bull. 97: 421-435.

Johnson, N. K., Zink, R. M., Barrowclough, G. F. and Marten, J. A. (1984) Suggested techniques for modern avian systematics. Wilson Bull. 96: 543-560.

Johnston, D. W. (1955) Mass bird mortality in Georgia, October, 1954. Oriole 20: 17-26.

Johnston, R. F. and Selander, R. K. (1971) Evolution in the House Sparrow II. Adaptive differentiation in North American populations. Evolution 25: 1-28.

Ketterson, E. D. and Nolan, V., Jr. (1986) Effect of laparotomy of Tree Sparrows and Dark-eyed Juncos during winter on subsequent survival in the field. J. Field Orn. 57: 239-240.

Klem, D., Jr. (1990) Collisions between birds and windows: mortality and prevention. J. Field Orn. 61: 120-128.

Kingsbury, P. A. (1975) Who took the birds out of British ornithology? Brit. Birds 68: 473 .

Kiff, L. F. and Hough, D. J. (1985) Inventory of bird egg collections of North America, 1985. Norman, Oklahoma: American Ornithologists' Union and Oklahoma Biological Survey.

Kinsky, F. C. and Harper, P. C. (1968) Shrinkage of bill width in skins of some Pachyptila species. Ibis 110: 100-102.

Knox, A. (1980) Post-mortem changes in wing-lengths and wing-formulae. Ringing and Migration 3: 29-31.

Lack, D. (1954) The natural regulation of animal numbers. Oxford, U.K.: Clarendon Press.

Lack, D. (1966) Population studies of birds. Oxford, U.K.: Clarendon Press.

Langston, N. E. and Rohwer, S. (1995) Unusual patterns of incomplete primary molt in Laysan and Black-footed albatrosses. Condor 97: 1-19.

Lanyon, S. M. (1992) Interspecific brood parasitism in blackbirds (Icterinae): a phylogenetic perspective. Science 255: 77-79.

Lederer, R. J. and Crane, R. (1978) The effects of emetics on wild birds. North Amer. Bird Bander 3: 3-5.

Lee, D. S. and Clark, M. K. (1993) Notes on post-breeding American Swallow-tailed Kites, Elanoides forficatus (Falconiformes: Accipitridae), in north central Florida. Brimleyana 19: 185-203.

Lee, D. S. and Socci, M. C. (1989) Potential effects of oil spills on seabirds and selected other oceanic vertebrates off the North Carolina coast. Occ. Pap. N. Carolina Biol. Survey 1989-1: 1-64.

Leeton, P., Christidis, L. and Westerman, M. (1993) Feathers from museum bird skins a good source of DNA for phylogenetic studies. Condor 95: 465-466.

Liversidge, R. (1975) Collecting capers. Bokmakierie 27: 27-28.

Magnin, G. (1991) Hunting and persecution of migratory birds in the Mediterranean region. Pp. 59-71 in T. Salathé, ed. Conserving migratory birds. Cambridge, U.K.: International Council for Bird Preservation (Techn. Publ. 12). 
Major, R. E. (1989) The effect of human observers on the intensity of nest predation. 1 bis 132: 608-612.

Marantz, C. A. and Remsen, J. V., Jr. (1991) Seasonal distribution of the Slaty Elaenia (Elaenia strepera), a little-known austral migrant of South America. J. Field Orn. 62: 162172 .

Marion, W. R. and Shamis, J. D. (1977) An annotated bibliography of bird marking techniques. J. Field Orn. 48: 42-61.

Marsden, J. E. and May, B. (1984) Feather pulp: a non-destructive sampling technique for electrophoretic studies of birds. Auk 101: 173-174.

Marshall, J. T., Jr. (1948) Ecological races of Song Sparrow in the San Francisco Bay region. Part II. Geographic variation. Condor 50: 233-256.

McGeehan, A. (1993) Enlightenment, not epitaphs. Birding 25: 129.

McGeehan, A. (1994) Enlightenment, not epitaphs. Birdwatch 23: 20.

McGowan, K. J. and Caffrey, C. (1994) Does drugging crows for capture cause abnormally high mortality? J. Field Orn. 65: 453-457.

Miller, A. H. (1959) Reproductive cycles in an equatorial sparrow. Proc. Natn. Acad. Sci. 45: 1095-1100.

Miller, A. H. (1962) Bimodal occurrence of breeding in an equatorial sparrow. Proc. Natn. Acad. Sci. 48: 396-400.

Miller, A. H. (1963) Seasonal activity and ecology of the avifauna of an American equatorial cloud forest. Univ. California Publ. Zool. 66: 1-78.

Miller, E. H. (1985) Museum collections and the study of animal social behavior. Pp. 139-162 in E. H. Miller, ed. Museum collections: their roles and future in biological research. British Columbia Prov. Mus. Occ. Pap. No. 25.

Mitchell, D. (1994) Editor's letter. Birdwatch 23: 2-3.

Møller, A. P. (1991) Sperm competition, sperm depletion, paternal care, and relative testis size in birds. Amer. Nat. 137: 882-906.

Morlan, J. and Erickson, R. A. (1983) A Eurasian Skylark at Point Reyes, California, with notes on skylark identification and systematics. West. Birds 14: 113-126.

Moser, M. L. and Lee, D. S. (1992) A fourteen-year survey of plastic ingestion by western North Atlantic seabirds. Colonial Waterbirds 15: 83-94.

Moyser, G. (1987) Points of view. Brit. Birds 80: 582.

Mulliken, T. A., Broad, S. R. and Thomsen, J. B. (1992) The wild bird trade - an overview. Pp. $1-4$ I in J. B. Thomsen, S. R. Edwards and T. A. Mulliken, eds. Perceptions, conservation and management of wild birds in trade. Cambridge, U.K.: Traffic International.

Mumme, R. L., Koenig, W. D., Zink, R. M. and Marten, J. A. (1985) An analysis of genetic variation and parentage in a California population of Acorn Woodpeckers. Auk 102: 305-312.

Myers, N. (1986) Tropical deforestation and a mega-extinction spasm. Pp.394-409 in M. E. Soulé, ed. Conservation biology, the science of scarcity and diversity. Sunderland, Massachusetts: Sinauer Associates.

Nickell, W. D. (1964) Fatal entanglements of Herring Gulls (Larus argentatus) and Common Terns (Sterna hirundo). Auk 81: 555-556.

Odin, N. (1994) Letter to the editor. Birdwatch 25: 30.

Ollason, J. C. and Dunnet, G. M. (1980) Nest failures in the Fulmar: the effect of observers. J. Field Orn. 51: 39-54.

Olson, S. L. (1994) The endemic vireo of Fernando de Noronha (Vireo gracilirostris). Wilson Bull. 106: 1-17.

Ouellet, H. (1993) Bicknell's Thrust: taxonomic status and distribution. Wilson Bull. 105: $545^{-572 .}$

Parker, T. A., III, and Bailey, B., eds. (1991) A biological assessment of the Alto Madidi region and adjacent areas of northwest Bolivia. Washington, D.C.: Conservation International, Rapid Assessment Working Papers 1. 
Parker, T. A., III, Bates, J. M. and Cox, G. (1992) Rediscovery of the Bolivian Recurvebill with notes on other little-known species of the Bolivian Andes. Wilson Bull, 104: 173178.

Parkes, K. C. (1963) The contribution of museum collections to knowledge of the living bird. Living Bird 2: 121-130.

Payne, R. B. (1982) Species limits in the indigobirds (Ploceidae, Vidua) of West Africa: mouth mimicry, song mimicry, and description of new species. Misc. Publ. Mus. Zool., Univ. Michigan No. 162.

Peterson, A. T. and Burt, D. B. (1992) A phylogenetic analysis of social evolution and habitat use in the Aphelocoma jays. Anim. Behav. 44: 859-866.

Phillips, A. R. (1974) The need for education and collecting. Bird-Banding 45: 24-28.

Phillips, A. R. (1975) Semipalmated Sandpiper: identifications, migrations, summer and winter ranges. Amer. Birds 29: 799-806.

Picozzi, N. (1975) Crow predation on marked nests. J. Wildl. Mgmt. 39: 151-155.

Pierpont, N. and Fitzpatrick, J. W. (1983) Specific status and behavior of Cymbilaimus sanctaemariae, the Bamboo Antshrike, from southwestern Amazonia. Auk 100: 645-652.

Porneluzi, P., Bednarz, J. C., Goodrich, L. J., Zawada, N. and Hoover, J. (1993) Reproductive performance of territorial ovenbirds occupying forest fragments and a contiguous forest in Pennsylvania. Conserv. Biol. 7: 618-622.

Poulin, B., Lefebvre, G. and McNeil, R. (1994) Effect and efficiency of tartar emetic in determining the diet of tropical land birds. Condor 96: 98-104.

Pyle, P. (1993) Collecting vagrants. Birding 25: 374-375.

Raikow, R. J. (1985) Museum collections, comparative anatomy and the study of phylogeny. Pp.113-122 in E. H. Miller, ed. Museum collections: their roles and future in biological research. British Columbia Prov. Mus. Occ. Pap. No. 25.

Ramos, M. A. (1988) Eco-evolutionary aspects of bird movements in the northern Neotropical region. Acta XIX Congr. Intern. Orn.: 251-293.

Raven, P. H. and Wilson, E. O. (1992) A fifty-year plan for biodiversity studies. Science 258: 1099-1100.

Recher, H. F., Gowing, G. and Armstrong, T. (1985) Causes and frequency of deaths among birds mist-netted for banding studies at two localities. Australian Wildl. Res. 12: $321-326$.

Remsen, J. V., Jr. (1984) Geographic variation, zoogeography, and possible rapid evolution in some Cranioleuca spinetails. Wilson Bull. 96: 515-523.

Remsen, J. V., Jr. (1985) Community organization and ecology of birds of high elevation humid forest of the Bolivian Andes. Pp. $733-756$ in P. A. Buckley, M. S. Foster, E. S. Morton, R. S. Ridgely and F. G. Buckley, eds. Neotropical ornithology. American Ornithologists' Union (Orn. Monogr. No. 36).

Remsen, J. V., Jr. (1991) Por que colectar especimenes de aves, con recomendaciones para la otorgación de permisos de colecta. Ecología en Bolivia 18: 52-68.

Remsen, J. V., Jr. (1993) Emotionalism is the epitaph for enlightenment. Birding 25: 129132.

Remsen, J. V., Jr., and Parker, T. A., III (1990) Seasonal distribution of the Azure Gallinule (Porphyrula flavirostris), with comments on vagrancy in rails and gallinules. Wilson Bull. 102: 380-399.

Richman, A. D. and Price, T. D. (1992) Evolution of ecological differences in the Old World leaf warblers. Nature 355: 817-821.

Richner, H. (1989) Avian laparoscopy as a field technique for sexing birds and an assessment of its effect on wild birds. J. Field Orn. 60: 137-142.

Ricklefs, R. E. (1980) Old specimens and new directions: the museum tradition in contemporary ornithology. Auk 97: 206-207.

Risebrough, R. W. (1986) Pesticides and bird populations. Current Orn. 3: 397-427. 
Robbins, C. S., Bystrak, D. and Geissler, P. H. (1986) The Breeding Bird Survey: its first fifteen years, 1965-1979. Washington, D.C.: U.S. Fish and Wildlife Service, U.S. Dept. Interior (Resource Publ. 57).

Robert, H. C. and Ralph, C. J. (1975) Effects of human disturbance on the breeding success of gulls. Condor 77: 495-499.

Robinson, S. K. (1992) Population dynamics of breeding Neotropical migrants in a fragmented landscape. Pp. 408-418 in J. M. Hagan, III, and D. W. Johnston, eds. Ecology and conservation of Neotropical migrant landbirds. Washington, D.C.: Smithsonian Institution Press.

Roby, D. D. (1991) A comparison of two noninvasive techniques to measure total body lipid in live birds. Auk 108: 509-518.

Rohwer, S. (1975) The social significance of avian winter plumage variability. Evolution 29: 593-610.

Ross, H. A. (1983) Genetic differentiation of Starling (Sturnus vulgaris: Aves) populations in New Zealand and Great Britain. J. Zool. 201: 351-362.

Rylander, M. K. (1967) A short history of ornithology at Tulane University. Proc. Louisiana Acad. Sci. 30: 87-90.

Sallee, G. W. (1978) Ingestion of fishing lures by Little Blue Herons. Bull. Oklahoma Orn. Soc. 11: 29.

Seymour, J. (1994) No way to treat a natural treasure. New Scientist (12 March): 32-35.

Seutin, G., Brawn, J., Ricklefs, R. E. and Bermingham, E. (1993) Genetic divergence among populations of a tropical passerine, the Streaked Saltator (Saltator albicollis). Auk 110: $117-126$.

Sharrock, J. T. R. (1986) Hunting, shooting and wildlife. Brit. Birds 79: 248-249.

Sheldon, F. H., Slikas, B., Kinnarney, M., Gill, F. B. and Silverin, B. (1992) DNA-DNA hybridization evidence of phylogenetic relationships among major lineages of Parus. Auk 109: 173-185.

da Silva, J. M. C. (1991) Sistemática e biogeografia da superespécie Nystalus maculatus (Piciformes: Bucconidae). Ararajuba 2: 75-79.

Simberloff, D. (1988) The contribution of population and community biology to conservation science. Annu. Rev. Ecol. Systematics 19: 473-511.

Skutch, A. F. (1985) Clutch size, nesting success, and predation on nests of Neotropical birds, revisited. Pp. 575-594 in P. A. Buckley, M. S. Foster, E. S. Morton, R. S. Ridgely and F. G. Buckley, eds. Neotropical ornithology. American Ornithologists' Union (Orn. Monogr. No. 36).

Smith, T. B., Freed, L. A., Lepson, J. K. and Carothers, J. H. (in press) Evolutionary consequences of extinctions in populations of a Hawaiian honeycreeper. Conserv. Biol.

Snow, D. W. (1980) A new species of cotinga from southeastern Brazil. Bull. Brit. Orn. Club 100: 213-215.

St. Louis, V. L. and Barlow, J. C. (1988) Genetic differentiation among ancestral and introduced populations of the Eurasian Tree Sparrow (Passer montantis). Evolution 42: $266-276$.

St. Louis, V. L. and Barlow, J. C. (1991) Morphometric analysis of introduced and ancestral populations of the Eurasian Tree Sparrow. Wilson Bull. 103: 1-12.

Stangel, P. W. (1986) Lack of effects from sampling blood from small birds. Condor 88: $244^{-245 .}$

Stevenson, H. M., Eisenmann, E., Winegarner, C. and Karlin, A. (1983) Notes on Common and Antillean nighthawks of the Florida Keys. Auk 100: 983-988.

Stiles, F. G. (1981) The taxonomy of rough-winged swallows (Stelgidopteryx; Hirundinidae) in southern Central America. Wilson Bull. 93: 282-293.

Stiles, F. G. (1983a) The taxonomy of Microcerculus wrens (Troglodytidae) in Central America. Wilson Bull. 95: 282-293. 
Stiles. F. G. (1983b) On sightings and specimens. Auk 100: 225-226.

Storer, R. W. (1988) The need for more museum specimens of colonial waterbirds. Colonial Waterbirds 11: 123-124.

Storer, R. W. (1992) Intraspecific variation and the identification of Pliocene and Pleistocene grebes. Nat. Hist. Mus. Los Angeles Co. Sci. Series 36: 419-422.

Terborgh, J., Robinson, S. K., Parker, T. A., III, Munn, C. A. and Pierpont, N. (1990) Structure and organization of an Amazonian forest bird community. Ecol. Monogr. 6o: $213^{-238 .}$

Thompson, C. W. and Leu, M. (1994) Determining homology of molts and plumages to address evolutionary questions: a rejoinder regarding emberizid finches. Condor 96: $769-782$.

Thompson, D. R., Furness, R. W. and Walsh, P. W. (1992) Historical changes in mercury concentrations in the marine ecosystem of the north and north-east Atlantic Ocean as indicated by seabird feathers. J. Appl. Ecol. 29: 79-84.

Tiersch, T. R. and Mumme, R. L. (1993) An evaluation of the use of flow cytometry to identify sex in the Florida Scrub Jay. J. Field Orn. 64: 18-26.

Vaurie, C. (1980) Taxonomy and geographical distribution of the Furnariidae (Aves, Passeriformes). Bull. Amer. Mus. Nat. Hist. 166: 1-357.

Walkinshaw, L. H. (1942) Aortic rupture in Field Sparrow due to fright. Auk 62: 141.

Walsberg, G. F. (1988) Evaluation of a nondestructive method for determining fat stores in small birds and mammals. Physiol. Zool. 61: 153-159.

Walsberg, G. F. (1993) The treatment of biologists by the U.S. Fish and Wildlife Service. Condor 95: 748-757.

Walsberg, G. F. (1994) The use of wild birds in research. Condor 96: 1119-1120.

Westmoreland, D. and Best, L. B. (1985) The effect of disturbance on Mourning Dove nest success. Auk 102: $774-780$.

Westneat, D. F. (1986) The effects of muscle biopsy on survival and condition of Whitethroated Sparrows. Wilson Bull. 98: 280-285.

Westneat, D. F., Payne, R. B. and Doehlert, S. M. (1986) Effects of muscle biopsy on survival and breeding success in Indigo Buntings. Condor 88: 220-227.

Willard, D. E., Foster, M. S., Barrowclough, G. F., Dickerman, R. W., Cannell, P. F., Coats, S. L., Cracraft, J. L. and O'Neill, J. P. (1991) The birds of Cerro de la Neblina, Territorio Federal Amazonas, Venezuela. Fieldiana (Zool.), New Ser., No. 65.

Winker, K. (1993) Specimen shrinkage in Tennessee Warblers and "Traill's" Flycatchers. J. Field Orn. 64: 331-336.

Winker, K., Fall, B. A., Klicka, J. T., Parmelee, D. F. and Tordoff, H. B. (1991) The importance of avian collections and the need for continued collecting. Loon 63: 238246.

Winker, K., Voelker, G. A. and Klicka, J. T. (1994) A morphometric examination of sexual dimorphism in the Hylophilus, Xenops, and an Automolus from southern Veracruz, Mexico. J. Field Orn. 65: 307-323.

Winkler, D. W. and Sheldon, F. H. (1993) Evolution of nest construction in swallows (Hirundinidae): a molecular phylogenetic perspective. Proc. Natn. Acad. Sci. 90: 57055707.

Wood, D. S. and Schnell, G. D. (1986) Revised world inventory of avian skeletal specimens, 1986. Norman, Oklahoma: American Ornithologists' Union and Oklahoma Biological Survey.

Woolfenden, G. E. and Fitzpatrick, J. W. (1991) Florida Scrub Jay ecology and conservation. Pp. $542-565$ in C. M. Perrins, J. D. Lebreton and G. J. M. Hirons, eds. Bird population studies: relevance to conservation and management. Oxford: Oxford University Press.

Zach, R. and Falls, J. B. (1976) Bias and mortality in the use of tartar emetic to determine the diet of Ovenbirds (Aves: Parulidae). Canad. J. Zool. 54: 1599-1603. 
Zink, R. M. (1983) Evolutionary and systematic significance of temporal variation in the Fox Sparrow. Syst. Zool. 32: 223-238.

Zink, R. M. (1988) Evolution of brown towhees: allozymes, morphometrics and species limits. Condor 90: $7^{2-82}$.

Zink, R. M. (1994) The geography of mitochondrial DNA variation, population structure, hybridization, and species limits in the Fox Sparrow (Passerella iliaca). Evolution 48: 96111.

Zink, R. M. and Dittmann, D. L. (1991) Evolution of brown towhees: mitochrondrial DNA evidence. Condor 93: 98-105.

Zink, R. M. and Kale, H. W. (in press) Conservation genetics of the extinct Dusky Seaside Sparrow. Biol. Conserv.

Zusi, R. L., Wood, D. S. and Jenkinson, M. A. (1982) Remarks on a world-wide inventory of avian anatomical specimens. Auk 99: 740-757.

J. V. REMSEN, JR.

Museum of Natural Science, Louisiana State University, Baton Rouge, Louisiana 70803, U.S.A. 